\title{
Bacterial Quorum Sensing: Its Role in Virulence and Possibilities for Its Control
}

\author{
Steven T. Rutherford ${ }^{1}$ and Bonnie L. Bassler ${ }^{1,2}$ \\ ${ }^{1}$ Department of Molecular Biology, Princeton University, Princeton, New Jersey 08544 \\ ${ }^{2}$ Howard Hughes Medical Institute, Chevy Chase, Maryland 20815 \\ Correspondence: bbassler@princeton.edu
}

Quorum sensing is a process of cell-cell communication that allows bacteria to share information about cell density and adjust gene expression accordingly. This process enables bacteria to express energetically expensive processes as a collective only when the impact of those processes on the environment or on a host will be maximized. Among the many traits controlled by quorum sensing is the expression of virulence factors by pathogenic bacteria. Here we review the quorum-sensing circuits of Staphylococcus aureus, Bacillus cereus, Pseudomonas aeruginosa, and Vibrio cholerae. We outline these canonical quorum-sensing mechanisms and how each uniquely controls virulence factor production. Additionally, we examine recent efforts to inhibit quorum sensing in these pathogens with the goal of designing novel antimicrobial therapeutics.

$\mathrm{Q}$ uorum sensing (QS) is a bacterial cell-cell communication process that involves the production, detection, and response to extracellular signaling molecules called autoinducers (AIs). AIs accumulate in the environment as the bacterial population density increases, and bacteria monitor this information to track changes in their cell numbers and collectively alter gene expression. QS controls genes that direct activities that are beneficial when performed by groups of bacteria acting in synchrony. Processes controlled by QS include bioluminescence, sporulation, competence, antibiotic production, biofilm formation, and virulence factor secretion (reviewed in Novick and Geisinger 2008; Ng and Bassler 2009; Williams and Camara 2009).
Despite differences in regulatory components and molecular mechanisms, all known QS systems depend on three basic principles. First, the members of the community produce AIs, which are the signaling molecules. At low cell density (LCD), AIs diffuse away, and, therefore, are present at concentrations below the threshold required for detection. At high cell density (HCD), the cumulative production of AIs leads to a local high concentration, enabling detection and response (Kaplan and Greenberg 1985). Second, AIs are detected by receptors that exist in the cytoplasm or in the membrane. Third, in addition to activating expression of genes necessary for cooperative behaviors, detection of AIs results in activation of AI production (Novick et al. 1995; Seed et al. 1995). This

Editors: Pascale Cossart and Stanley Maloy

Additional Perspectives on Bacterial Pathogenesis available at www.perspectivesinmedicine.org

Copyright (C) 2012 Cold Spring Harbor Laboratory Press; all rights reserved; doi: 10.1101/cshperspect.a012427

Cite this article as Cold Spring Harb Perspect Med 2012;2:a012427 
feed-forward autoinduction loop presumably promotes synchrony in the population.

Gram-positive and Gram-negative bacteria use different types of QS systems (Fig. 1 shows the four paradigmatic QS wiring diagrams). Gram-positive bacteria use peptides, called autoinducing peptides (AIPs), as signaling molecules. Once produced in the cell, AIPs are processed and secreted. When the extracellular concentration of the AIP is high, which occurs at $\mathrm{HCD}$, it binds to a cognate membrane-bound two-component histidine kinase receptor. Usually, binding activates the receptor's kinase activity, it autophosphorylates, and passes phosphate to a cognate cytoplasmic response regulator. The phosphorylated response regulator activates transcription of the genes in the QS regulon (Fig. 1A). In some cases of Gram-positive bacterial QS, AIPs are transported back into the cell cytoplasm where they interact with transcription factors to modulate the transcription factor's activity and, in turn, modulate gene expression changes (Fig. 1B).

Gram-negative bacteria communicate using small molecules as AIs. These are either acyl- homoserine lactones (AHLs) or other molecules whose production depends on S-adenosylmethionine (SAM) as a substrate (Wei et al. 2011). AIs are produced in the cell and freely diffuse across the inner and outer membranes. When the concentration of AIs is sufficiently high, which occurs at HCD, they bind cytoplasmic receptors that are transcription factors. The AI-bound receptors regulate expression of the genes in the QS regulon (Fig. 1C). In some cases of Gram-negative bacterial QS, AIs are detected by two-component histidine kinase receptors that function analogously to those described in the preceding paragraph for Gram-positive QS bacteria (Fig. 1D).

Dozens of clinically-relevant bacteria use QS to regulate the collective production of virulence factors. Here, we highlight the QS systems of four human pathogens that exemplify the diversity of QS systems. First, we outline how Staphylococcus aureus uses the paradigmatic Agr system to regulate adhesion and production of virulence factors. We also discuss the $\mathrm{PlcR} / \mathrm{PapR}$ system that controls virulence factor production in the Gram-positive bacterium Bacillus cereus.
A

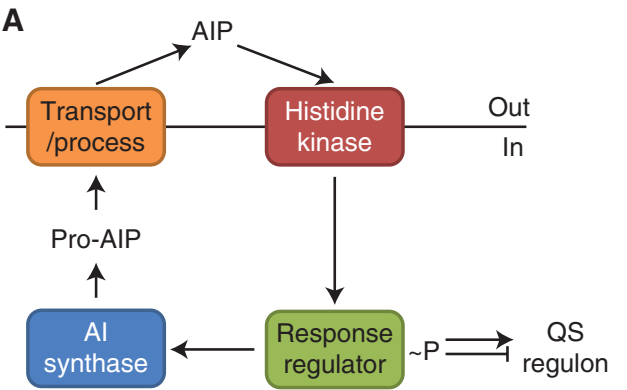

C

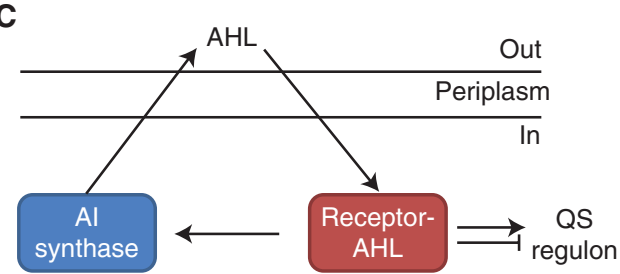

B

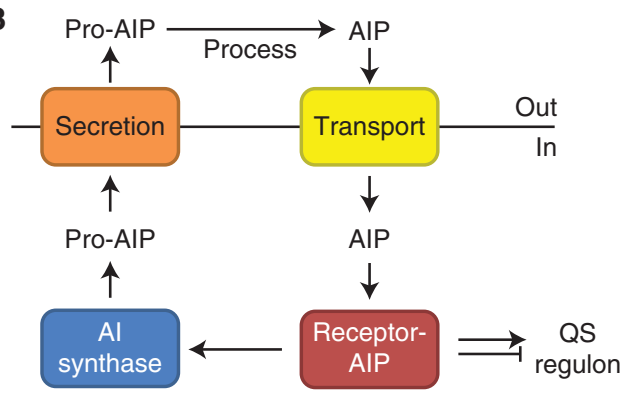

D

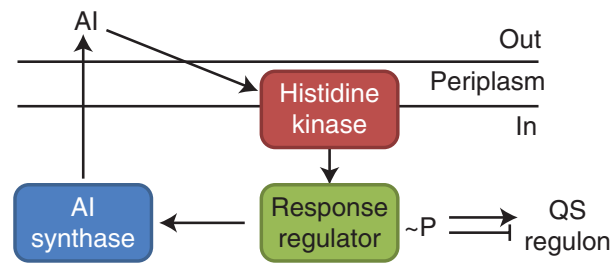

Figure 1. Canonical bacterial quorum-sensing (QS) circuits. Autoinducing peptide (AIP) QS in Gram-positive bacteria by $(A)$ two-component signaling, or $(B)$ an AIP-binding transcription factor. Small molecule QS in Gram-negative bacteria by $(C)$ a LuxI/LuxR-type system, or $(D)$ two-component signaling. 
Next, we describe the canonical Gram-negative LuxI/LuxR QS circuit and how Pseudomonas aeruginosa exploits two such circuits arranged in tandem to control virulence factor production and biofilm formation. Finally, we discuss QS in Vibrio cholerae, a Gram-negative bacterium that uses two parallel two-component QS systems to control virulence factor production and biofilm formation. Importantly, in all of these cases, the QS circuits are tailored to promote the specific disease. P. aeruginosa and $S$. aureus cause persistent diseases while $V$. cholerae and $B$. cereus cause acute infections. We also outline efforts to develop inhibitors of these QS systems to be deployed as novel antimicrobials.

\section{QS CONTROL OF VIRULENCE FACTORS IN GRAM-POSITIVE BACTERIA}

\section{Two-Component QS in Gram-Positive Bacteria}

QS in Gram-positive bacteria relies on principles common to all QS circuits: production, detection, and response to AIs. In many Grampositive bacteria, the AIs are oligopeptide AIPs that are detected by membrane-bound twocomponent signal transduction systems (Fig. 1A) (Havarstein et al. 1995; Ji et al. 1995; Solomon et al. 1996).

The AIPs are encoded as precursors (proAIPs) and are diverse in sequence and structure (Havarstein et al. 1995; Otto et al. 1998; Lazazzera 2001; Nakayama et al. 2001; Kalkum et al. 2003; Okada et al. 2005; Thoendel et al. 2011). Because the cell membrane is impermeable to peptides, specialized transporters are required to secrete AIPs. The AIP transporters also process the pro-AIPs. The final processed AIPs range in size from 5 to 17 amino acids, can be posttranslationally modified, and can be linear or cyclized (Magnuson et al. 1994; Havarstein et al. 1995; Mayville et al. 1999; Okada et al. 2005; Bouillaut et al. 2008). Extracellular AIPs are detected via membrane-bound two-component sensor kinases (Hoch and Silhavy 1995; Inouye and Dutta 2003; Simon et al. 2007). The sensor kinases autophosphorylate at conserved histi- dines when bound by the AIP. The phosphoryl group is passed from the histidine to a conserved aspartate on a cognate cytoplasmic response-regulator protein, and the phosphorylated response regulator controls expression of QS-target genes. In these Gram-positive QS circuits, the pro-AIP, transporter, histidine kinase receptor, and response regulator are typically encoded in an operon (Ji et al. 1995; Peterson et al. 2000). Expression of this operon is activated by the phosphorylated response regulator, resulting in an autoinducing feed-forward loop that synchronizes the QS response.

Some examples of Gram-positive QS behaviors are competence in Streptococcus pneumonia and Bacillus subtilis and sporulation in B. subtilis (Kleerebezem et al. 1997). QS controls virulence factor production in Gram-positive human pathogens including $S$. aureus, Listeria monocytogenes, Enterococcus faecalis, and Clostridium perfringens (Autret et al. 2003; Podbielski and Kreikemeyer 2004; Ohtani et al. 2009; Riedel et al. 2009; Thoendel et al. 2011). The most well-studied system in this group of pathogens is the $S$. aureus Agr system (reviewed extensively in Thoendel et al. 2011).

\section{S. aureus Quorum Sensing}

S. aureus is found among the normal human skin flora. If the epithelial barrier is compromised, $S$. aureus can cause minor skin infections. These infections can lead to pneumonia, bacteremia, and sepsis (Lowy 1998; Massey et al. 2006). S. aureus is the leading cause of hospitalrelated infections in the United States. Its ability to cause disease depends on expression of an array of adhesion molecules, toxins, and compounds that affect the immune system. QS regulates expression of genes encoding these virulence factors.

S. aureus uses a canonical Gram-positive two-component QS system encoded by the $a g r$ locus (Fig. 2). The P2 promoter drives expression of a transcript (RNAII), which encodes the four components of the QS system (Novick et al. 1995). agrD encodes the pro-AIP, which is processed to the final AIP and secreted by the transmembrane transporter protein AgrB (Ji et al. 


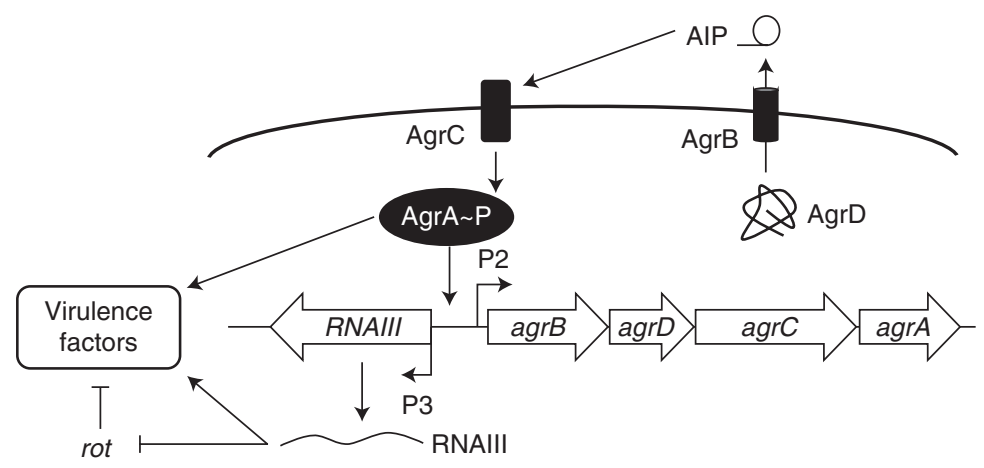

Figure 2. S. aureus Agr QS circuit. The autoinducing peptide (AIP) is synthesized as a precursor from agrD. The AIP transporter AgrB processes the precursor to the mature AIP and transports it out of the cell. AIPs are detected by a two-component signal transduction pathway. AgrC is the membrane-bound histidine kinase and AgrA is the response regulator. Phosphorylated AgrA activates the P2 and P3 promoters encoding the agr operon (called RNAII) and the RNAIII regulatory RNA, respectively. RNAIII posttranscriptionally activates virulence factor production and represses expression of rot, the repressor of toxins, leading to further derepression of virulence factors.

1995; Saenz et al. 2000; Thoendel and Horswill 2009, 2010; Thoendel et al. 2011). Processing involves truncating the 45-47 residue pro-AIP to a 7-9 residues peptide, coupled with cyclization of a five-membered peptide ring via a thiolactone bond between a central cysteine residue and the carboxyl terminus (Table 1). When the AIP accumulates, it binds the membrane-bound histidine kinase AgrC, which autophosphorylates at a conserved histidine and transfers the phosphate group to an aspartate on the response regulator AgrA (Lina et al. 1998). Phosphorylated AgrA binds upstream of the P2 promoter to autoinduce the agr operon (Novick et al. 1995).

In addition to activating the $\mathrm{P} 2$ promoter, phosphorylated AgrA activates the divergently encoded P3 promoter. The P3 promoter controls expression of RNAIII (Novick et al. 1993). The $5^{\prime}$ region of RNAIII harbors the hld gene, which encodes the virulence factor $\delta$-hemolysin (Janzon and Arvidson 1990). A more prominent role for RNAIII is as a regulatory RNA (Novick et al. 1993). RNAIII has the dual-function of activating production of $\alpha$-toxin and repressing expression of $r o t$, fibronectin binding proteins $\mathrm{A}$ and $\mathrm{B}$, protein $\mathrm{A}$, coagulase, and other surface proteins (Morfeldt et al. 1995; Dunman et al. 2001). Repression of rot, which encodes a repressor of toxins, leads to de-repres- sion of additional toxins, proteases, lipases, enterotoxins, superantigens, and urease (SaidSalim et al. 2003; Geisinger et al. 2006). The net result of this QS regulatory cascade is downregulation of surface virulence factors (such as protein A), and up-regulation of secreted virulence factors (such as $\alpha$-toxin). Most of the effects of $Q S$ on regulation of virulence in $S$. aureus are mediated through direct and indirect regulation by RNAIII, however, phosphorylated AgrA also directly activates at least two additional virulence genes encoding phenol-soluble modulines (Queck et al. 2008).

Another key component of the $S$. aureus virulence program is biofilm development. In S. aureus, the agr system inhibits biofilm formation (Vuong et al. 2000; Boles and Horswill 2008). One interpretation of this finding is that establishing a biofilm community at LCD allows $S$. aureus time to grow to HCD and, at that point, it is optimally poised to secrete virulence factors (Yarwood et al. 2004; Boles and Horswill 2008). To facilitate its dispersal, S. aureus terminates biofilm production and decreases surface proteins and adhesions at HCD. This behavior is analogous to the strategy used by V. cholerae (see below).

Numerous additional regulatory factors converge at the $\mathrm{P} 2$ and $\mathrm{P} 3$ promoters, which add 
Table 1. S. aureus AIPs and inhibitors

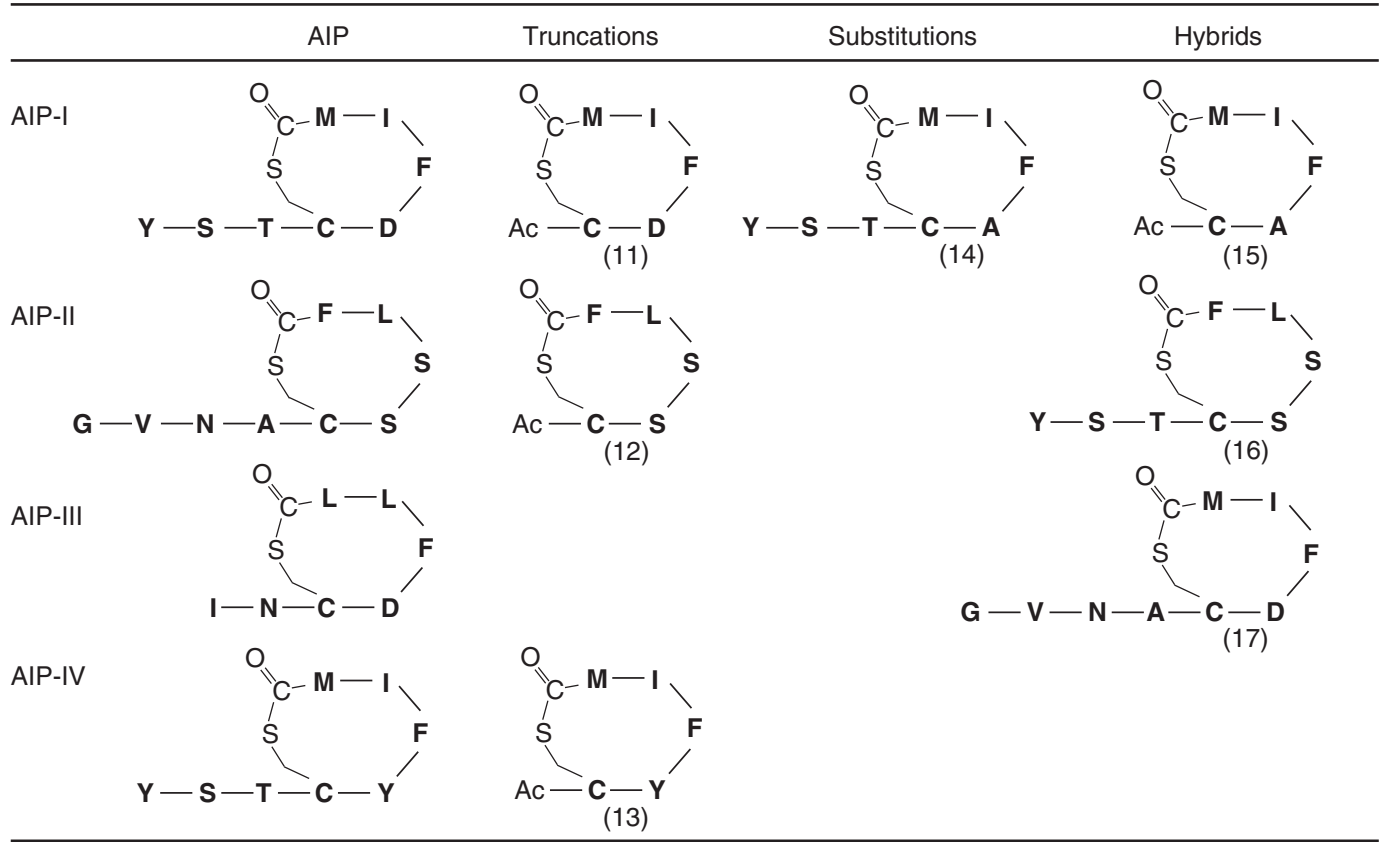

Inhibitors 11, 13, 15, 16, and 17 are from (Lyon et al. 2002); inhibitor 12 is from (Lyon et al. 2000); and inhibitor 14 is from (McDowell et al. 2001).

layers of regulation to the S. aureus QS circuitry, presumably ensuring that the QS program is expressed under the most ideal situations. There is evidence for regulation by ArlRS, CcpA, CodY, Rsr, $\sigma^{\mathrm{B}}$, SarA, SarR, SarT, SarU, SarX, SarZ, Rsr, and SrrA/SrrB (Cheung and Projan 1994; Schmidt et al. 2001; Yarwood et al. 2001; Manna and Cheung 2003, 2006a,b; Liang et al. 2005; Seidl et al. 2006; Majerczyk et al. 2008; Lauderdale et al. 2009; Tamber and Cheung 2009; Tamber et al. 2010). One of the interesting themes common to several of these accessory agr regulators is that they provide $S$. aureus the ability to respond to extracellular environmental signals, in addition to AIPs, using the QS circuitry. For example, following extracellular stress, the alternative sigma factor $\sigma^{\mathrm{B}}$ interacts with core RNAP to direct transcription of surface proteins and pigment production, and inhibit expression of secreted toxins and proteases. RNAIII levels also increase when the $\sigma^{\mathrm{B}}$ gene is deleted (Lauderdale et al. 2009). No consensus sequence for $\sigma^{\mathrm{B}}$ exists at the $\mathrm{P} 2$ or $\mathrm{P} 3$ promoters, so it is likely that $\sigma^{\mathrm{B}}$ regulates some as- yet-unknown regulator of agr. $\sigma^{\mathrm{B}}$ regulation presumably ensures that $S$. aureus does not undergo QS, which is energetically costly, under conditions when the bacteria must dedicate resources to alleviating stress. Another example involves CodY, which responds to isoleucine limitation in S. aureus. Deletion of $\operatorname{cod} Y$ increases RNAII and RNAIII expression (Majerczyk et al. 2008; Pohl et al. 2009). CodY binding sites are located in the $\operatorname{agr} C$ gene (Majerczyk et al. 2010). Thus, CodYallows S. aureus to delay its QS response until it exists in a nutrient-rich environment. Finally, the SrrA/SrrB two-component system, which regulates gene expression in response to anaerobic environments, also controls the $\mathrm{P} 2$ and $\mathrm{P} 3$ promoter region via SrrB binding (Yarwood et al. 2001). Overexpression of SrrA/ SrrB decreases virulence, likely due, at least in part, to inhibition of agr expression. Again, this regulation is thought to ensure that $\mathrm{QS}$ is not undertaken in a less than ideal environment.

A final interesting aspect of the $S$. aureus QS system is cross-competition among AIP specificity types. Hypervariability exists in the agrD 
gene and a portion of the agrB gene (Dufour et al. 2002). This variability leads to production of one of four different types of S. aureus AIPs depending on the strain (Table 1). The identity of the AIP allows typing of $S$. aureus into four specificity groups (I-IV) (Ji et al. 1997; Jarraud et al. 2000). A corresponding hypervariability exists in the portion of the agrC gene encoding the sensing domain of the AIP receptor (Dufour et al. 2002). Thus, each specific AIP is detected by a coevolved cognate AgrC sensor. The presence of a noncognate AIP results in inhibition of QS, highlighting the specific nature of the AIPreceptor interactions. Specificity is proposed to be determined sterically and binding of the incorrect AIP-type can lead to stabilization of an inhibitory confirmation of AgrC, thus halting cell-cell signaling (Mayville et al. 1999; Lyon et al. 2002; Geisinger et al. 2009). The biological consequence of this mechanism is that the first strain to establish its QS cascade in the host is the one that causes the infection (Fleming et al. 2006).

\section{S. aureus QS as a Therapeutic Target}

The prevalence of $S$. aureus infections coupled with the emergence of methicillin-resistant S. aureus (MRSA) highlight the importance of studying and controlling this pathogen (Brumfitt and Hamilton-Miller 1989). The rationale for targeting the $S$. aureus QS system is that agr mutants are defective in virulence. The principal target considered to date is the receptor AgrC. Because the AIPs naturally cross-inhibit, analyses of their variations coupled with synthetic chemistry have provided a mechanistic understanding of AIP antagonism. By varying the length (Table 2, peptides 11-13) or amino acid sequence (Table 2, peptides 14 ) of the AIP or by combining substitutions and truncations to make hybrid AIPs (Table 2, peptides 15-17), universal inhibitors capable of out-competing all four AIP types have been designed (Lyon et al. 2000, 2002; McDowell et al. 2001).

The AIPs themselves have also been targeted for inhibition by inactivation through interaction with specific antibodies. The AIPs are poor antigens, however, monoclonal antibodies aga- inst AIPs coupled to carriers have been raised and are promising (Park et al. 2007). For example, screening of a library of monoclonal antibodies identified one antibody that reduced RNAIII and toxin production. This antibody acts as a highly-specific QS quencher.

One of the concerns with targeting the S. aureus QS system is the trade-off between virulence factor production and biofilm formation (Otto 2004). Inhibition of agr causes S. aureus to become more adherent because of increased biofilm formation. This facet of the circuit can lead to persistent colonization by S. aureus, which is of utmost concern for medically-implanted devices. Although there are reports that deletion of agr does not enhance biofilm formation under all conditions (Shenkman et al. 2001), targeting agr will likely become one part of a combination therapy for combating $S$. aureus and MRSA.

\section{QS by Peptide-Binding Transcription Factors in Gram-Positive Bacteria}

Some Gram-positive bacteria use a QS system in which AIPs, following release, are imported back into the cell and detected by cytoplasmic transcription factors (Fig. 1B). In these systems, the pro-AIP is secreted and processed into the mature AIP by extracellular proteases. Following transport back into the cell, the AIP binds to and alters the activity of a transcription factor (Slamti and Lereclus 2002).

Some examples of Gram-positive systems in which AIPs are imported include sporulation, competence, and enzyme production in B. subtilis (Pottathil and Lazazzera 2003) and plasmid transfer in E. faecalis (Dunny 2007). Additionally, AIP-bound transcription factors control virulence factor production in the Bacillus cereus group (Slamti and Lereclus 2002; Bouillaut et al. 2008) and we describe this system here (see review by Rocha-Estrada et al. 2010).

\section{B. cereus Quorum Sensing}

The B. cereus group of Gram-positive bacteria consists of several closely-related bacteria relevant to human health including $B$. cereus, $B$. 
anthrasis, and B. thuringiensis. B. cereus causes both intestinal and nonintestinal infections in humans and is most commonly associated with food poisoning (Bottone 2010). Its ability to cause acute diarrheal disease is caused by the production and secretion of a variety of hemolysins, phospholipases, and toxins (Bottone 2010).

QS in B. cereus requires the transcription factor PlcR, which controls expression of most B. cereus virulence factors following binding to the intracellular AIP derived from the PapR protein (Fig. 3) (Slamti and Lereclus 2002).papR is encoded 70 basepairs downstream of $p l c R$. PapR is 48 amino acids long and contains an aminoterminal signal peptide that targets it for the secretory pathway (Okstad et al. 1999). Once outside the cell, the PapR pro-AIP is processed by the secreted neutral protease $\mathrm{B}(\mathrm{NprB})$ to form the active AIP (Pomerantsev et al. 2009). $n p r B$ is encoded divergently from $p l c R$ and $n p r B$ expression is activated by AIP-bound PlcR (Okstad et al. 1999). NprB cleaves the pro-AIP PapR into peptides of $5,7,8$, and 11 amino acids in length, all of which are derived from the carboxyl terminus of full-length PapR (Pomerantsev et al. 2009). Only the pentapetide and heptapeptide activate PlcR activity, however, the heptapeptide causes maximal activation and is more prevalent in vivo (Bouillaut et al. 2008; Pomerantsev et al. 2009).

Similar to the $S$. aureus Agr system (see above), there is sequence diversity in the PapR
AIPs that enables classification of members of the $B$. cereus group into four pherotypes. Specificity for the PlcR receptor stems from the identities of the first and fifth amino acids in the pentapetides: $\mathrm{LPFE}(\mathrm{F} / \mathrm{Y}), \mathrm{VP}(\mathrm{F} / \mathrm{Y}) \mathrm{E}(\mathrm{F} / \mathrm{Y})$, MPFEF, and LPFEH (Slamti and Lereclus 2005). There is low cross-reactivity with heterologous PlcRs, indicating that the AIP and its receptor (PlcR) coevolved (Slamti and Lereclus 2005). Another interesting aspect of the pherotypes is that some contain different species, and can therefore communicate across species, whereas in other cases, different isolates of the same species fall into different subgroups and are prevented from communicating with one another (Slamti and Lereclus 2005; Rocha-Estrada et al. 2010).

The processed PapR AIP is imported back into the cell by the oligopeptide permease system (Opp) (Fig. 3) (Gominet et al. 2001). Once inside the cell, the AIP binds to the transcription factor $\mathrm{PlcR}$, and this causes conformational changes in the DNA-binding domain of PlcR, facilitates PlcR oligomerization, DNA binding, and regulation of transcription (Declerck et al. 2007).

When PlcR interacts with the PapR AIP and oligomerizes, it binds to "PlcR boxes" to regulate transcription of target genes (Agaisse et al. 1999). PlcR controls expression of 45 genes, many of which encode extracellular proteins including several enterotoxins, hemolysins, phos-

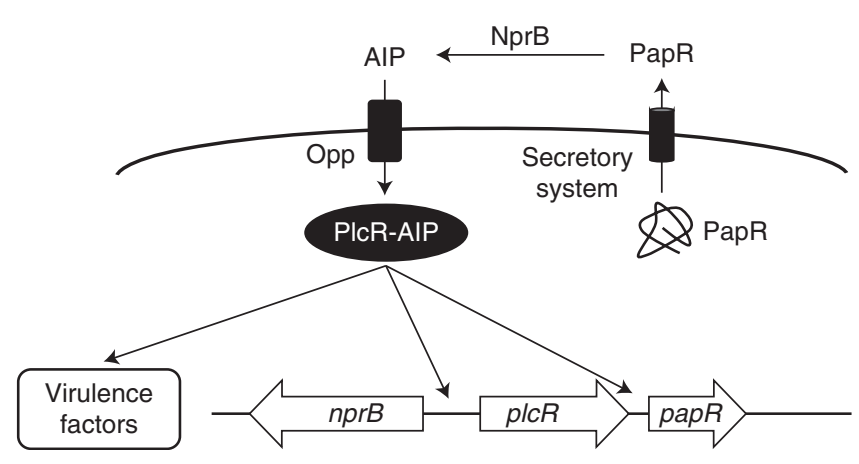

Figure 3. B. cereus QS circuit. The pro-AIP PapR is secreted and is then processed to the mature heptapeptide AIP by the extracellular protease NprB. The mature AIP is transported back into the cell by Opp. Intracellular AIP binds to the transcription factor PlcR and activates it. The PlcR-AIP complex regulates virulence factor production and activates expression of papR. 
pholipases, and proteases (Lereclus et al. 1996; Gohar et al. 2002, 2008). As is the case in all QS systems, AIP-bound PlcR also feedback activates expression of $p a p R$ (Lereclus et al. 1996). In addition to its role in regulating extracellular virulence factors, AIP-bound PlcR has other regulatory targets. These include two-component systems, transport systems, and GGDEF-containing proteins (Gohar et al. 2008). Finally, deletion of $p l c R$ results in increased biofilm production (Hsueh et al. 2006). However, despite its important role in regulating virulence factor production, disruption of plcR does not fully eliminate virulence (Lereclus et al. 2000; Callegan et al. 2003) because several additional systems feed into the B. cereus QS circuit and virulence factor regulation. These additional sensory inputs include sporulation through SpoOA $\sim \mathrm{P}$, nutritional state through CodY, motility through FlhA, and other two-component systems (Lereclus et al. 2000; Bouillaut et al. 2005; Brillard et al. 2008; Frenzel et al. 2012).

To date, no anti-PlcR/PapR QS molecules or screens for inhibitors of QS in B. cereus have been reported. Analogous to the $S$. aureus antiQS strategies described above, the B. cereus AIPs could certainly be investigated for development into QS inhibitors. The NprB protease, the Opp transporter, and the PlcR receptor are other obvious candidates for exploration of whether or not they are vulnerable to small molecule inhibition.

\section{QS CONTROL OF VIRULENCE IN GRAM-NEGATIVE BACTERIA}

\section{LuxI/LuxR Quorum Sensing}

Gram-negative bacteria typically use LuxI/LuxRtype QS systems homologous to the first described QS system from the bioluminescent marine symbiotic bacterium Vibrio fischeri (Fig. 1C) (Ruby 1996; Hastings and Greenberg 1999). In these systems, the LuxI homolog is an AI synthase that catalyzes a reaction between SAM and an acyl carrier protein (ACP) to produce a freely diffusible acyl homoserine lactone (AHL) AI (Engebrecht and Silverman 1984; More et al. 1996; Schaefer et al. 1996; Ng and Bassler
2009). At high concentrations, AHL AIs bind to cognate cytoplasmic LuxR-like transcription factors. When not bound by AI, LuxR-type proteins are rapidly degraded, presumably to prevent bacteria from "short-circuiting" their QS systems. AI binding stabilizes the LuxR-type proteins, allowing them to fold, bind DNA, and activate transcription of target genes (Engebrecht et al. 1983; Engebrecht and Silverman 1984; Stevens et al. 1994; Zhu and Winans 1999, 2001). Typically, AHL-bound LuxR-type proteins also activate luxI expression, forming a feed-forward autoinduction loop that floods the vicinity with AI (Engebrecht et al. 1983; Fuqua and Winans 1994; Seed et al. 1995).

LuxI/LuxR homologs have been identified in more than 100 Gram-negative bacterial species (Case et al. 2008). AHLs produced by different bacteria possess different length side chains and side-chain decorations. Acyl chains ranging from $\mathrm{C} 4$ to $\mathrm{C} 18$ have been identified with modifications such as carbonyl and hydroxy moieties at the C3 position (Fuqua et al. 2001; Ng and Bassler 2009). This chemical diversity promotes intraspecies-specific bacterial cell-cell communication in that interactions with partner LuxR proteins are usually highly specific. The substrate binding pockets of the various LuxI homologs have correspondingly different sizes and shapes, ensuring accommodation of only a particular acyl-ACP for synthesis of a particular AI (Watson et al. 2002; Gould et al. 2004). Likewise, the AI-detecting LuxR homologs possess unique binding pockets that specifically accommodate particular AHL ligands (Vannini et al. 2002; Zhang et al. 2002; Yao et al. 2006; Bottomley et al. 2007; Chen et al. 2011).

Numerous Gram-negative pathogens control virulence factor production using LuxI/LuxRtype QS circuits. Some examples are LasI/LasR and RhlI/RhlR in P. aeruginosa, SmaI/SmaR in Serratia marcescens, VjbR (an orphan LuxR homolog) in Brucella melitensis, and CviI/CviR in Chromobacterium violaceum (Passador et al. 1993; Brint and Ohman 1995; McClean et al. 1997; Thomson et al. 2000; Weeks et al. 2010). We describe the $P$. aeruginosa systems as the canonical example here (reviewed in detail in Williams and Camara 2009). 


\section{P. aeruginosa QS}

$P$. aeruginosa is a ubiquitous Gram-negative bacterium that can cause both acute and chronic infections in humans (Chugani and Greenberg 2007; Mena and Gerba 2009). P. aeruginosa infection generally depends on the host having a compromised immune system. Typically, $P$. aeruginosa infections are found in the lungs of people with cystic fibrosis (Lyczak et al. 2002; Zemanick et al. 2011). This infection leads to detality. $P$. aeruginosa also causes acute infections in people with compromised epithelial barriers; a common trait among patients with severe burns or tracheal intubation and mechanical ventilation (Bielecki et al. 2008). In both scenarios, P. aeruginosa uses QS to collectively produce a suite of virulence factors that contribute to its disease-causing ability.

P. aeruginosa harbors three QS systems: two LuxI/LuxR-type QS circuits that function in series to control expression of virulence factors as well as a third, non-LuxI/LuxR-type system called the Pseudomonas quinolone signal (PQS) system (Fig. 4). In the first circuit, the LuxI homolog LasI synthesizes 3-oxo-C12-homoserine lactone (3OC12HSL) (Table 2) (More et al. 1996; Val and Cronan 1998; Parsek et al. 1999; Gould et al. 2004; Bottomley et al. 2007). At $\mathrm{HCD}$, this AI is detected by the cytoplasmic LuxR homolog LasR. The LasR-3OC12HSL complex activates transcription of target genes including those encoding virulence factors such as elastase, proteases, and exotoxin A (Gambello and Iglewski 1991; Gambello et al. 1993; Schuster et al. 2003, 2004). One of the LasR-3OC12HSL targets is lasI, which establishes an autoinducing feed-forward loop (Seed et al. 1995). Another target of regulation by LasR-3OC12HSL is a second luxI homolog called rhlI (Latifi et al. 1996; Pesci et al. 1997). RhlI synthesizes a second AI, butanoyl homoserine lactone (C4HSL) (Table 2) (Ochsner et al. 1994; Pearson et al. 1995). At high concentrations, this AI binds to RhlR, a second LuxR homolog. RhlR-C4HSL activates target genes, including those encoding elastase, proteases, pyocyanin, and siderophores (Schuster et al. 2003; Schuster and Greenberg 2007). Among

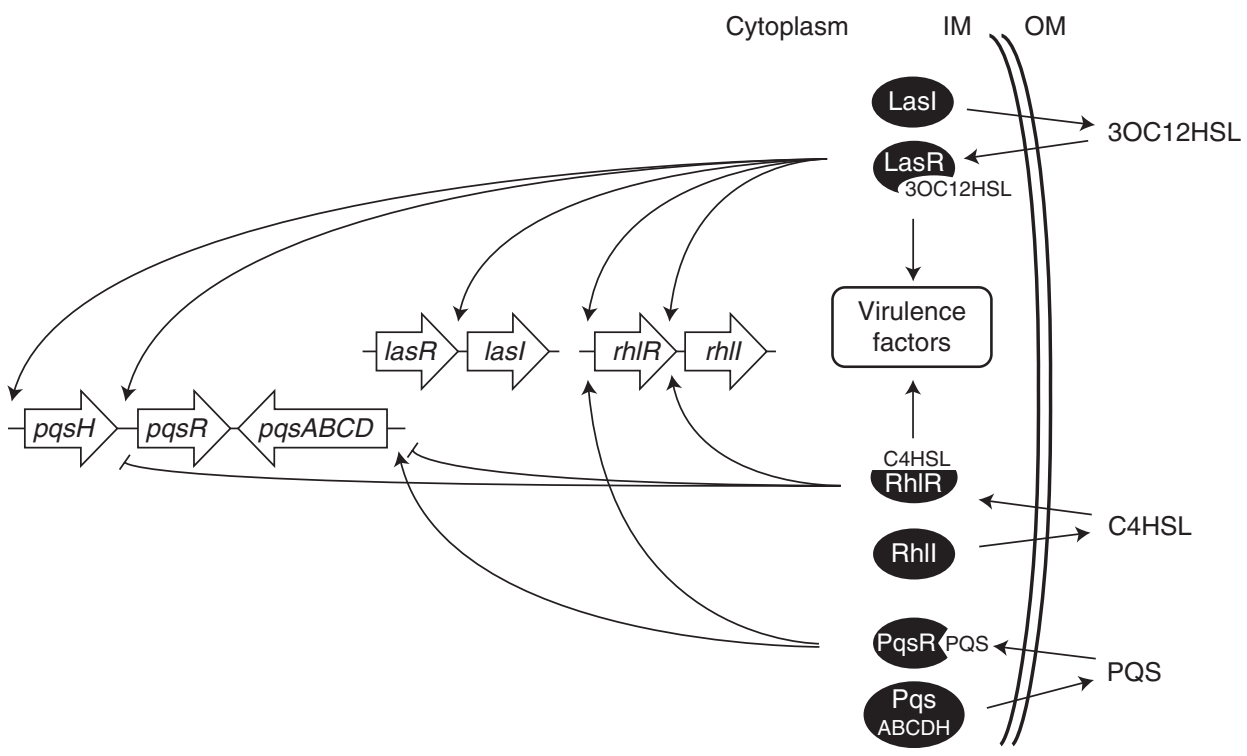

Figure 4. P. aeruginosa QS circuits. The three AI sythases, LasI, RhlI, and PqsABCDH, produce the AIs 3OC12HSL, C4HSL, and PQS, respectively. The AIs are detected by the cytoplasmic transcription factors LasR, RhlR, and PqsR, respectively. Each transcription factor regulates expression of its corresponding AI synthase as well as additional targets as indicated by the arrows. 


\section{S.T. Rutherford and B.L. Bassler}

Table 2. P. aeruginosa Als and inhibitors

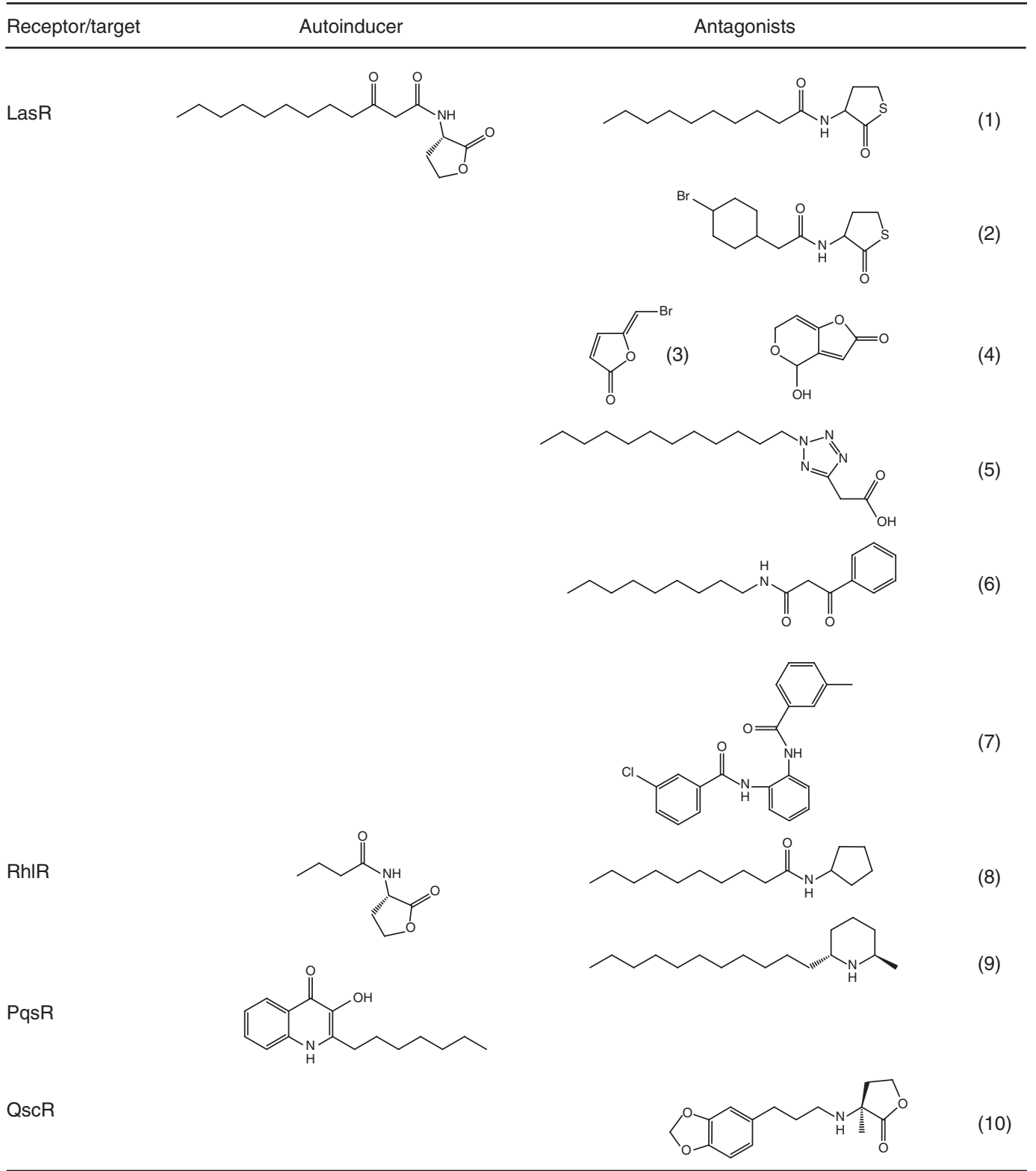

The three AIs (and their cognate receptors) are 3OC12HSL (LasR), C4HSL (RhIR), and PQS (PqsR). Inhibitors 1 and 2 are modified from 3OC12HSL by McInnis and Blackwell (2011); inhibitor 3 is a furanone described in Hentzer et al. (2002) and Wu et al. (2004); inhibitor 4 is patulin described in Rasmussen et al. (2005); inhibitors 5 and 6 are from a chemical library described in Muh et al. (2006b); inhibitor 7 is a triphenyl derivative from Muh et al. (2006a); inhibitor 8 is C10-acylcyclopentylamine from Ishida et al. (2007); inhibitor 9 is solenopsin from Park et al. (2008); and compound 10 is propanoyl homoserine lactone from Mattmann et al. (2008). 
its targets is rhlI, leading to autoinduction of this second QS circuit.

The crystal structure of the ligand binding domain of LasR bound to 3OC12HSL has been solved, revealing interactions between the receptor protein and the AI (Bottomley et al. 2007). Structures of other LuxR-type QS regulators, TraR, SdiR, and CviR, have also been solved enabling comparative analysis (Vannini et al. 2002; Zhang et al. 2002; Yao et al. 2006; Chen et al. 2011). In all cases, the common lactone head group of each AHL is bound by conserved residues in the binding pocket, whereas the residues forming the pockets for the different acyl tails are diverse. Comparing the LasR binding pocket for 3OC12HSL with the TraR binding pocket for 3OC8HSL shows different sizes and hydrophobic characteristics in the channels that accommodate the different acyl chains. These structures coupled with biochemical data indicate that binding of ligand to the receptor stabilizes folding of the hydrophobic core of the protein. Once folded properly, LasR (and presumably other LuxR-type receptors) can dimerize, bind DNA, and activate transcription (Zhu and Winans 2001; Kiratisin et al. 2002; Schuster et al. 2004; Urbanowski et al. 2004).

$P$. aeruginosa uses an additional non-LuxI/ LuxR QS system to control virulence factor gene expression. PQS, 2-heptyl-3-hydroxi-4-quinolone, is produced by $\mathrm{PqsA}, \mathrm{PqsB}, \mathrm{PqsC}, \mathrm{PqsD}$, and $\mathrm{PqsH}$ and is detected by the regulator $\mathrm{PqsR}$ (also called MvfR) (Fig. 4 and Table 2). Expression of $p q s H$ and $p q s R$ is activated by LasR3OC12HSL, whereas RhlR-C4HSL represses $p q s A B C D$ and $p q s R$ (Gallagher et al. 2002; Deziel et al. 2004; Xiao et al. 2006b). PqsR-PQS autoinduces PQS synthesis and further activates rhlI and rhlR expression (Xiao et al. 2006a; Diggle et al. 2007). Thus, the PQS circuit is intimately tied to the LasI/LasR and RhlI/RhlR QS systems and, therefore, also influences virulence factor production.

$P$. aeruginosa $\mathrm{QS}$-activated virulence factors include elastase, proteases, pyocyanin, lectin, swarming motility, rhamnolipids, and toxins. Although distinct regulons for LasR-3OC12HSL and RhlR-C4HSL have been reported, it is apparent that there is extensive overlap be- tween the regulons (Whiteley et al. 1999; Schuster et al. 2003, 2004; Wagner et al. 2004; Schuster and Greenberg 2007). Thus, most genes originally thought to be targeted only by LasR or only by RhlR can in fact be activated by either one. For example, a $\Delta$ las $R$ mutant, which is defective for rhlI induction, expresses virulence factors originally reported to be LasR-dependent (Dekimpe and Deziel 2009). Apparently, low level $r h l I$ and $r h l R$ expression promotes the eventual accumulation of C4HSL and autoinduction of the RhlI/RhlR system. Accordingly, activation of virulence factors is delayed in the $\Delta$ lasR strain. These findings are of medical relevance because many clinical isolates of $P$. aeruginosa possess mutations in lasR (Smith et al. 2006).

Another QS-controlled activity in $P$. aeruginosa is biofilm formation. Although regulation of biofilm formation in $P$. aeruginosa largely depends on additional environmental signals, QS regulation of rhamnolipids, swarming motility, and siderophores also contribute to $P$. aeruginosa biofilm formation (Ochsner et al. 1994; Deziel et al. 2003; De Kievit 2008; Patriquin et al. 2008; Rahman et al. 2010).

Up to $10 \%$ of the $P$. aeruginosa genome is controlled by QS (Schuster and Greenberg 2006), thus it is not surprising that there are additional levels of regulation impinging on the QS circuits. Vfr, AlgR, PhoR/B, RpoN, RpoS, DksA, RelA, GidA, QscR, RsmY, RsmZ, RsmA, PrrF, PhrS, VqsM, VqsR, and RsaL have all been reported to feed information into the $P$. aeruginosa QS circuit (Albus et al. 1997; de Kievit et al. 1999; Branny et al. 2001; Pessi et al. 2001; van Delden et al. 2001; Heurlier et al. 2003; Ledgham et al. 2003; Medina et al. 2003; Hogardt et al. 2004; Juhas et al. 2004; Dong et al. 2005; Jensen et al. 2006; Morici et al. 2007; Schuster and Greenberg 2007; Gupta et al. 2009; Sonnleitner et al. 2010). These accessory regulators of $P$. aeruginosa QS presumably fine-tune the network so that virulence factor production occurs with optimal precision. Indeed, when AIs are added to exponentially growing $P$. aeruginosa, they do not induce expression of the entire QS regulon (Schuster and Greenberg 2007). Only when cells are exposed to stimuli 
associated with stationary phase as well as AIs is the complete set of QS targets launched. Although there are several fascinating regulatory events, here we highlight only two posttranscriptional regulation mechanisms.

\section{QscR}

QscR is an orphan LuxR homolog that does not have a partner LuxI homolog. QscR can, however, bind to the AI produced by LasI, 3OC12HSL (Lequette et al. 2006; Lintz et al. 2011; Oinuma and Greenberg 2011). Additionally, it forms mixed dimers with LasR and RhlR, rendering them inactive (Ledgham et al. 2003). Thus, QscR likely prevents aberrant QS responses before the cells reaching "a quorum."

\section{sRNAs}

Small regulatory RNAs (sRNAs) in bacteria act by basepairing with mRNA targets to repress or activate gene expression (reviewed in Gottesman 2004; Papenfort and Vogel 2010; Storz et al. 2011). In P. aeruginosa, the sRNAs PrrF1, PrrF2, and PhrS regulate the PQS system in response to limiting iron (PrF1 and PrrF2) or limiting oxygen (PhrS) (Wilderman et al. 2004; Sonnleitner et al. 2010; Sonnleitner and Haas 2011). PhrS stimulates translation of an open reading frame in the $5^{\prime}$ end of the $p q s R$ mRNA and this action activates $p q s R$ translation by altering the secondary structure surrounding the pqrR RBS (Sonnleitner et al. 2010). PrrF1 and PrrF2 repress expression of genes encoding enzymes that degrade a precursor of PQS (anthranilate), thus allowing increased PQS under low iron conditions (Oglesby et al. 2008; OglesbySherrouse and Vasil 2010; Sonnleitner and Haas 2011). Two other sRNAs involved in $P$. aeruginosa QS regulation are RsmY and RsmZ, sRNAs that are activated by the GacS/GacA two-component system in response to limiting magnesium and other unknown signals (Kay et al. 2006; Mulcahy and Lewenza 2011; O’Callaghan et al. 2011). RsmY and RsmZ repress the transcription factor RsmA, which, in turn, represses production of both 3OC12HSL and C4HSL (Pessi et al. 2001; Kay et al. 2006).

\section{P. aeruginosa QS as a Therapeutic Target}

The $P$. aeruginosa QS circuits make attractive targets for novel antimicrobials because QS controls virulence factor production and no homologs to known QS components exist in humans. This is especially critical in the treatment of persistent infections in cystic fibrosis patients given the resistance of many $P$. aeruginosa isolates to available antibiotics. Small molecule inhibitors of $P$. aeruginosa QS have been extensively reviewed (Mattmann and Blackwell 2010). Here we highlight a few recent advances.

Because LasR sits at the top of the P. aeruginosa QS cascade, identifying LasR inhibitors has been a major focus. Competitive inhibitors have been reported that contain modifications to the native 3OC12HSL ligand (Geske et al. 2005, 2007, 2008; Mattmann and Blackwell 2010; McInnis and Blackwell 2011). In this realm, alterations to both the head group and the acyl tail have led to molecules that out-compete 3OC12HSL for binding to LasR (Table 2, compounds 1 and 2). Importantly, some of these modifications, such as substitution of the lactone ring for a thiolactone ring (McInnis and Blackwell 2011), are useful because of their increased stability under biological conditions. Second, natural products have been isolated that inhibit QS by antagonizing LasR (Hentzer et al. 2002; Wu et al. 2004; Rasmussen et al. 2005; Ren et al. 2005; Kim et al. 2008). These inhibitors include furanones and patulin (Table 2, compounds 3 and 4, respectively), which have been further modified to increase their efficacy. Finally, high-throughput screens of small molecule libraries have revealed additional scaffolds for the design of inhibitors (Muh et al. 2006a,b; Borlee et al. 2010) (for example, Table 2, compounds 5-7). A potential complication in targeting LasR is that, as mentioned, some clinical $P$. aeruginosa isolates possess defective LasR proteins (Smith et al. 2006). Nonetheless, establishment of the initial infection is known to be LasI/LasR-dependent, suggesting that, at a minimum, LasR inhibitors could be used as prophylactics.

Other factors involved in $P$. aeruginosa QS have also been targeted for drug discovery. For 
example, inhibitors of LasR have been successfully modified to act as competitive inhibitors of RhlR and in some cases these molecules have proven to be potent inhibitors of both LasR and RhlR (Table 2, compound 8) (Smith et al. 2003; Glansdorp et al. 2004; Ishida et al. 2007). Natural products have been isolated that inhibit RhlR (Table 2, compound 9) (Park et al. 2008).

A final approach is to target regulators that affect both the LasI/LasR and RhlI/RhlR QS systems. For example, a small molecule library was screened for agonists and antagonists of QscR, which, as described, influences both the LasI/LasR and RhlI/RhlR systems (Lee et al. 2006; Mattmann et al. 2008, 2011; Amara et al. 2009; Liu et al. 2010). By agonizing QscR, it could be possible to diminish the overall QS response and thus prevent or delay expression of virulence factors. Interestingly, some non-natural AHLs that target QscR also inhibit LasR, raising the intriguing possibility of a compound that can act broadly to target all of the P. aeruginosa QS systems (Table 2, compound 10) (Mattmann and Blackwell 2010).

\section{V. cholerae Quorum Sensing}

$V$. cholerae is the causative agent of the disease cholera (Faruque et al. 1998). This diarrheal disease is endemic in underdeveloped regions and has epidemic and pandemic potential, especially when clean water supplies are compromised. The principal symptom of the disease, profuse watery diarrhea, can lead to dehydration and death if not properly treated. This symptom is caused by an enterotoxin called cholera toxin, expression of which is controlled by QS (Jobling and Holmes 1997; Zhu et al. 2002).

V. cholerae, a Gram-negative bacterium, produces and responds to two AIs using two parallel QS circuits. One AI is (S)-3-hyroxytridecan4-one (CAI-1), which is synthesized by the CqsA enzyme using SAM and decanoyl-coenzyme A as substrates (Table 3) (Higgins et al. 2007; Ng et al. 2011; Wei et al. 2011). Homologs of CqsA have been identified in all vibrio species consistent with a proposed role for CAI-1 as an intergenus communication molecule, allowing communication among other vibrios harboring
cqsA (Miller et al. 2002; Henke and Bassler 2004; Higgins et al. 2007). The second AI, AI-2, is synthesized by LuxS. LuxS converts the SAM cycle intermediate $S$-ribosylhomocysteine to 4,5 -dihydroxy-2,3-penanedionine (DPD) and homocysteine. DPD spontaneously converts into AI-2 (Table 3) (Surette et al. 1999; Schauder et al. 2001; Chen et al. 2002). Homologs of luxS exist in hundreds of Gram-negative and Gram-positive bacteria, consistent with a role for AI-2 in interspecies communication that allows other luxS-encoding bacteria in a particular environment to contribute to the overall cell-density information (Federle and Bassler 2003; Xavier and Bassler 2005). Thus, using two different AIs presumably allows $V$. cholerae to detect both the number of other vibrios and the total number of bacteria in the environment.

V. cholerae detects CAI- 1 and AI- 2 using two parallel membrane-bound two-component receptors (Fig. 5). CqsS detects CAI-1 and LuxPQ detects AI-2 (Bassler et al. 1994; Neiditch et al. 2005, 2006; Ng et al. 2010, 2011). In the absence of ligand, at LCD, both of these receptors function as kinases. Upon autophosphorylation, CqsS and LuxPQ transfer phosphate to the shared response regulator LuxO via the phosphotransfer protein LuxU (Bassler et al. 1994; Freeman and Bassler 1999a,b; Lilley and Bassler 2000). Phosphorylated LuxO activates expression of genes encoding four homologous quorum-regulatory sRNAs, called Qrr1-4 (Lenz et al. 2004). Transcription of the qrr sRNA genes is directed by the alternative sigma factor $\sigma^{54}$. To date, the four qrr promoters and the luxO promoter itself are the only known targets for regulation by LuxO.

At LCD, the Qrr sRNAs are expressed and regulate target mRNAs by base-pairing. The principal targets of the Qrr RNAs are the mRNAs encoding the master QS regulators HapR and AphA (Lenz et al. 2004; Rutherford et al. 2011). However, the Qrr sRNAs have opposite effects on these two mRNA targets. The QrrsRNAs base-pair with the hapR mRNA overlapping the RBS, prevent ribosome binding, and facilitate degradation of $h a p R$ mRNA (Lenz et al. 2004; Tu and Bassler 2007). The Qrr sRNAs activate production of $a p h A$ by binding to the 
S.T. Rutherford and B.L. Bassler

Table 3. V. cholerae Als and inhibitors

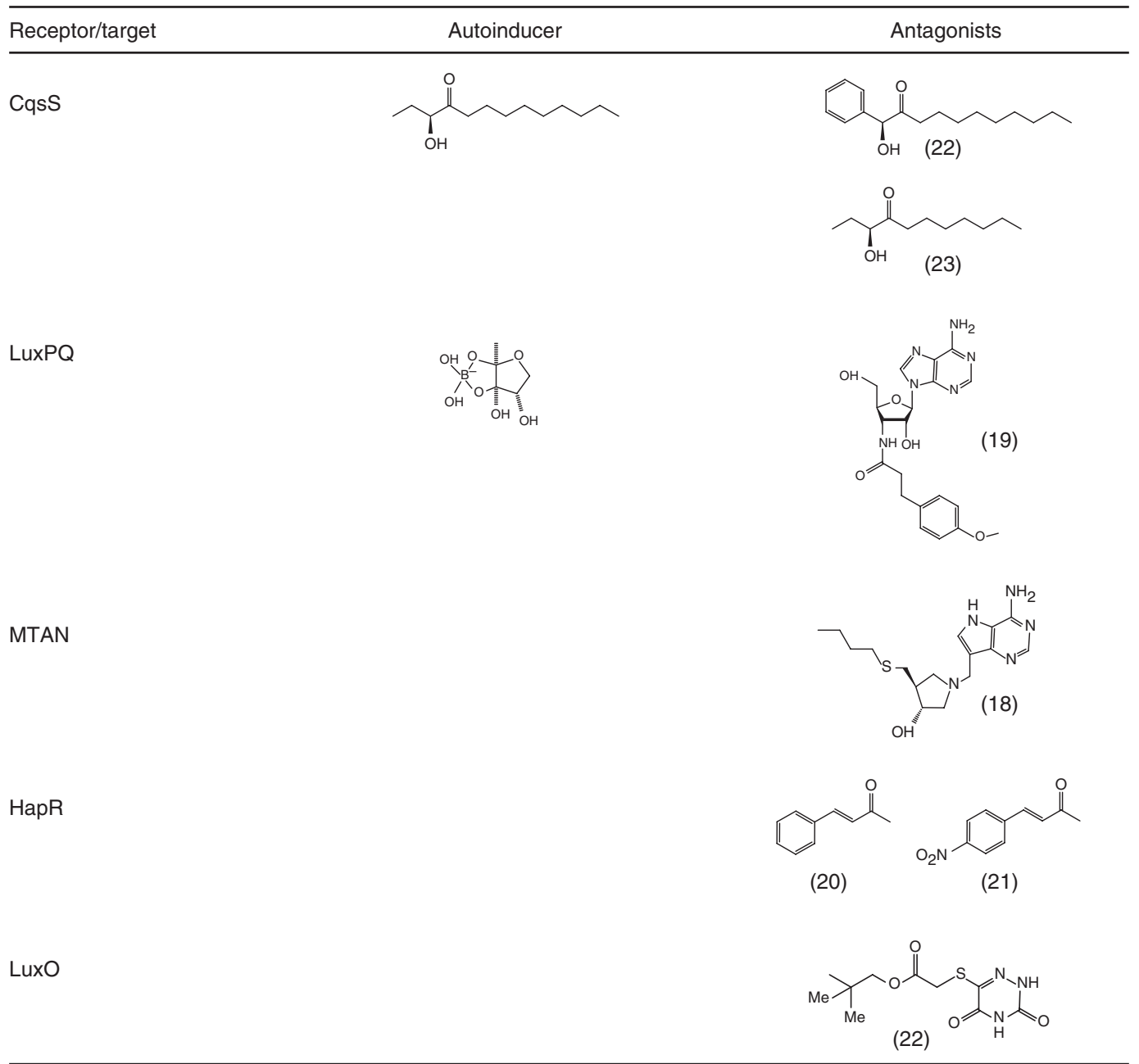

The autoinducers are CAI-1 and AI-2. Inhibitor 18 is a MTAN transition state analog from Schramm et al. (2008); inhibitor 19 is a modified nucleoside from Brackman et al. (2009); inhibitors 20 and 21 are cinnamaldehydes described in Niu et al. (2006); Brackman et al. (2008, 2011); compounds 22 (phenyl-CAI-1) and 23 (C8-CAI-1) are from Ng et al. (2010); and compound 24 a 6-thio-5-azauracil derivative from $\mathrm{Ng}$ et al. (2012).

untranslated region of the aphA mRNA and inducing an alternative secondary structure, which reveals the RBS to allow translation (Rutherford et al. 2011; Shao and Bassler 2012). Thus, at LCD, the Qrr sRNAs prevent hapR expression and activate aphA expression so that HapR levels are low and AphA levels are high.

When CAI- 1 and AI-2 accumulate at HCD, they bind CqsS and LuxPQ, respectively, which switches the receptors to phosphatases (Neiditch et al. 2006; Ng et al. 2010). It is not known how AI-2 impinges on in the LuxPQ kinase/ phosphatase reaction but CAI-1 functions by inhibiting CqsS autophosphorylation (Wei et al. 2012). CAI-1 has no effect on the phosphotransfer step or the CqsS phosphatase activity (Wei et al. 2012). Once bound by AIs, LuxPQ and CqsS de-phosphorylate LuxO, leading to cessation of $q r r$ expression, and the freeing of the hapR mRNA for translation. In the absence of Qrr sRNAs, in contrast, the aphA mRNA assumes a conformation refractory to 


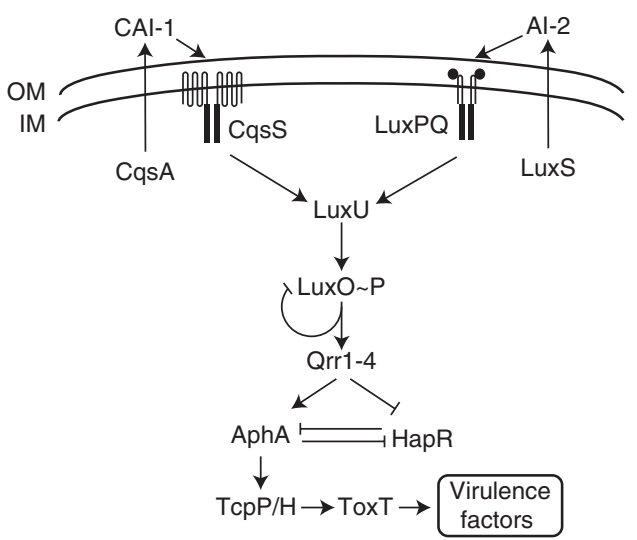

Figure 5. V. cholerae QS circuit. V. cholerae detects CAI-1 (produced by CqsA) and AI-2 (produced by LuxS) via two two-component histidine kinases, CqsS and LuxPQ, respectively. In the absence of AIs at $\mathrm{LCD}$, the receptors function as kinases resulting in phosphorylation of $\mathrm{LuxO}$, via $\mathrm{LuxU}$, and activation of qrr gene expression. The Qrr sRNAs activate aphA and repress hapR expression. AphA represses hapR and activates $t c p P H$. TcpPH activates toxT expression and ToxT activates expression of the major virulence factors. At HCD, AIs bind the receptors switching them to phosphatases resulting in dephosphorylation of LuxO, cessation of qrr gene expression, and increased hapR expression. HapR represses $a p h A$ to shut down virulence factor production.

ribosome binding. The two master QS regulators are thus produced in reciprocal gradients with AphA highest at LCD and HapR highest at $\mathrm{HCD}$. This dichotomy is reinforced by mutual repression whereby AphA represses hapR expression and HapR represses aphA expression (Kovacikova and Skorupski 2002; Lin et al. 2007; Pompeani et al. 2008; Rutherford et al. 2011).

Interestingly, $V$. cholerae expresses its suite of virulence factors at LCD (Jobling and Holmes 1997; Zhu et al. 2002). At LCD, AphA, a wingedhelix transcription factor, works together with a LysR-type transcription factor, AphB, to activate transcription of $t c p P H$ (Kovacikova and Skorupski 1999, 2001; Skorupski and Taylor 1999). TcpP is a trans-membrane DNA binding protein, the function of which is enhanced by TcpH (Carroll et al. 1997; Beck et al. 2004; Matson et al. 2007). TcpPH activates expression of
toxT. ToxT is a transcription factor that activates expression of the genes encoding cholera toxin and the toxin co-regulated pilus, which are the major V. cholerae virulence factors (Fig. 5) (Higgins et al. 1992; Withey and DiRita 2006; Matson et al. 2007). Expression of toxT is also activated by ToxRS, which is homologous to TcpPH (Peterson and Mekalanos 1988; Skorupski and Taylor 1997; Matson et al. 2007).

Along with other regulators, QS also controls biofilm formation in $V$. cholerae (Hammer and Bassler 2003; Zhu and Mekalanos 2003). Biofilm formation is activated at LCD and repressed at HCD. HapR, expressed at HCD, plays a major role in this aspect of the program. First, HapR directly represses genes encoding components of the biofilm factory (Yildiz et al. 2004). Second, HapR represses expression of two transcription factors that activate biofilm formation genes, VpsR and VpsT (Beyhan et al. 2007; Waters et al. 2008; Shikuma et al. 2009; Srivastava et al. 2011). Third, HapR represses expression of genes required for the synthesis of the second messenger cyclic-di-GMP (Lim et al. 2006, 2007; Waters et al. 2008). Cyclic-di-GMP is sensed through the transcription factor VpsT to activate biofilm formation (Krasteva et al. 2010). This LCD biofilm lifestyle allows $V$. cholerae to remain attached to host tissue when virulence factors are expressed. At HCD, QS repression of biofilms and virulence factor production facilitates dispersal of $V$. cholerae back into the environment. This strategy allows $V$. cholerae to maximally compete for nutrients in the host at LCD and maximize its ability to exit and spread to other hosts once it reaches HCD (Nadell and Bassler 2011). Because a high infective dose is required, the host serves as the incubator, and it appears that when the titer is high enough to ensure infection of a new host, the population is dispersed.

\section{V. cholerae QS Components as Targets for Therapeutics}

The V. cholerae QS circuit has several possible targets for the discovery or design of novel antimicrobial agents. Some interesting approaches have targeted pathways involved in the synthesis 
of the AIs. In the SAM cycle, MTAN, which is found only in bacteria, is a hydrolase that turns over methylthioadenosine to maintain the homeostatic SAM pool. This step is critical for the synthesis of both CAI-1 and AI-2 (Schauder et al. 2001; Wei et al. 2011). A synthetic inhibitor of MTAN blocks QS in V. cholerae without affecting growth (Table 3, compound 18) (Schramm et al. 2008). This MTAN inhibitor blocks AI-2 production in enterohemorrhagic Escherichia coli as well. In a screen for nucleoside analogs able to disrupt AI-2 QS, another molecule was identified that disrupts AI-2-based QS without affecting growth in $V$. harveyi, a close relative of $V$. cholerae (Table 3, compound 19) (Brackman et al. 2009). This compound likely targets the signaling pathway for the AI-2 receptor, LuxPQ, which is present in numerous vibrio species including V. cholerae (Fig. 5).

Cinnamaldehyde is a natural product that inhibits QS in vibrios (Niu et al. 2006). Cinnamaldehyde and derivatives are proposed to target HapR and its homologs (Table 3, compounds 20 and 21), thus inhibiting virulence factor production and biofilm formation without dramatically affecting growth (Brackman et al. 2008,2011 ). These compounds increase survival of model host nematodes infected with different vibrios leading to the interesting possibility that HapR can be regulated by a cell permeable ligand.

Several synthetic ligands of the receptor CqsS have been identified. Using these molecules has been instrumental in determining the mechanism of signal recognition and discrimination in $V$. cholerae QS. For example, CqsS does not respond to CAI-1 molecules with bulky head groups (Table 3, compound 22) or shortened tail groups (Table 3, compound 23) ( $\mathrm{Ng}$ et al. 2010). Indeed, such molecules are CqsS antagonists. Owing to the fact that $V$. cholerae expresses virulence factors at LCD in the absence of AIs, CqsS represents an interesting target because compounds that prematurely trigger QS (i.e., potent CqsS agonists) could prevent virulence factor expression.

Finally, in addition to the receptors and the transcription factor HapR, intermediate components in the QS circuit are targets for thera- peutics. For example, a high-throughput chemical screen led to the identification of a LuxO antagonist (Ng et al. 2012). The molecule and potent analogs are all 6-thio-5-azauracil derivatives (Table 3, compound 24, for example). This family of molecules uncompetitively bind the preformed LuxO-ATP complex and inhibit ATP hydrolysis, which prevents transcription activation. When inhibited, LuxO is not able to activate expression of the qrr sRNA genes, thus locking $V$. cholerae into HCD mode and preventing expression of virulence factors (Fig. 5). Because LuxO exists in all vibrio QS circuits, this family of molecules has broad spectrum antivirulence activity in marine vibiros ( $\mathrm{Ng}$ et al. 2012).

\section{CONCLUDING REMARKS}

QS is a vital regulatory mechanism used by many bacteria to control collective traits that allow bacteria to exploit particular niches. For example, QS enables access of symbionts to nutrient-rich environments in hosts (Ruby 1996). Bacterial populations use QS to control biofilm formation, which provides members of the population superior access nutrients and thus enables them to out-compete non-biofilm-producing neighbors (Nadell and Bassler 2011). Finally, as discussed in the above examples, bacteria that make their living by exploiting eukaryotic hosts have coupled production of the virulence factors necessary for a pathogenic lifestyle to their ability to detect changes in cell population density.

Four trends emerge when considering the examples described above. First, it is clear that QS gene regulation is the result of regulatory networks layered onto the basic AI production and detection apparatuses. Because of the global genetic programs controlled by QS, these additional regulatory mechanisms likely ensure that altered gene expression occurs only under precisely-defined conditions. Alternatively, given that QS regulates global gene expression patterns, perhaps other regulatory systems have co-opted QS systems to control additional products in response to particular environmental conditions. Second, it is interesting that in the 
cases described here, as well as in other cases, QS is linked to biofilm production. Although the mechanism and timing of production differ among these species, in each case, QS plays a role in dictating when this process occurs. Members of biofilm communities most certainly benefit from the ability to communicate and, likewise, bacterial communication is probably more robust when the cells are in the intimate associations provided by biofilms. Third, there appears to be a prominent role for regulation involving sRNAs. QS controls expression of hundreds of genes and a commitment to a lifestyle that could be detrimental to the individual. One of the general benefits of regulation by sRNAs is the rapidity with which regulation can occur because translation and protein folding are not required to produce the regulator. Thus, it is possible that QS systems rely heavily on sRNAs to quickly adjust global gene expression programs as bacteria transition between disparate niches. Finally, small molecules analogous to those involved in QS are increasingly becoming recognized as key modulators of pathogenic behaviors and important players in biofilm formation in bacteria. Thus, strategies aimed at manipulating small molecule control of bacterial behaviors are now viewed as especially promising. Presumably, therapies that affect bacterial behavior will not be as prone to resistance as are the targets of traditional antibiotics that result in outright killing of bacteria or inhibition of their growth. Thus, therapeutics that interfere with small molecule-controlled pathways could have longer functional shelf lives than second and third generation antibiotics.

\section{ACKNOWLEDGMENTS}

We thank members of the Bassler Laboratory for insightful discussion and especially Dr. WaiLeung Ng, Dr. Julia van Kessel, and Ms. Colleen O'Loughlin for helpful suggestions. S.T.R. is supported by an NRSA postdoctoral fellowship F32AI085922 and work in the Bassler Laboratory is supported by the Howard Hughes Medical Institute, National Institutes of Health (NIH) grant 5R01GM065859, NIH grant 5R01AI0
54442, and National Science Foundation (NSF) grant MCB-0343821.

\section{REFERENCES}

Agaisse H, Gominet M, Okstad OA, Kolsto AB, Lereclus D. 1999. PlcR is a pleiotropic regulator of extracellular virulence factor gene expression in Bacillus thuringiensis. Mol Microbiol 32: 1043-1053.

Albus AM, Pesci EC, Runyen-Janecky LJ, West SE, Iglewski BH. 1997. Vfr controls quorum sensing in Pseudomonas aeruginosa. J Bacteriol 179: 3928-3935.

Amara N, Mashiach R, Amar D, Krief P, Spieser SA, Bottomley MJ, Aharoni A, Meijler MM. 2009. Covalent inhibition of bacterial quorum sensing. J Am Chem Soc 131: 10610-10619.

Autret N, Raynaud C, Dubail I, Berche P, Charbit A. 2003. Identification of the agr locus of Listeria monocytogenes: Role in bacterial virulence. Infect Immun 71: 4463-4471.

Bassler BL, Wright M, Silverman MR. 1994. Multiple signalling systems controlling expression of luminescence in Vibrio harveyi: Sequence and function of genes encoding a second sensory pathway. Mol Microbiol 13: 273-286.

Beck NA, Krukonis ES, DiRita VJ. 2004. TcpH influences virulence gene expression in Vibrio cholerae by inhibiting degradation of the transcription activator TcpP. J Bacteriol 186: 8309-8316.

Beyhan S, Bilecen K, Salama SR, Casper-Lindley C, Yildiz FH. 2007. Regulation of rugosity and biofilm formation in Vibrio cholerae: Comparison of VpsT and VpsR regulons and epistasis analysis of vpsT, vpsR, and hapR. J Bacteriol 189: 388-402.

Bielecki P, Glik J, Kawecki M, Martins dos Santos VA. 2008. Towards understanding Pseudomonas aeruginosa burn wound infections by profiling gene expression. Biotechnol Lett 30: 777-790.

Boles BR, Horswill AR. 2008. Agr-mediated dispersal of Staphylococcus aureus biofilms. PLoS Pathog 4: e1000052.

Borlee BR, Geske GD, Blackwell HE, Handelsman J. 2010. Identification of synthetic inducers and inhibitors of the quorum-sensing regulator LasR in Pseudomonas aeruginosa by high-throughput screening. Appl Environ Microbiol 76: 8255-8258.

Bottomley MJ, Muraglia E, Bazzo R, Carfi A. 2007. Molecular insights into quorum sensing in the human pathogen Pseudomonas aeruginosa from the structure of the virulence regulator LasR bound to its autoinducer. $J$ Biol Chem 282: 13592-13600.

Bottone EJ. 2010. Bacillus cereus, a volatile human pathogen. Clin Microbiol Rev 23: 382-398.

Bouillaut L, Ramarao N, Buisson C, Gilois N, Gohar M, Lereclus D, Nielsen-Leroux C. 2005. FlhA influences $B a$ cillus thuringiensis PlcR-regulated gene transcription, protein production, and virulence. Appl Environ Microbiol 71: 8903-8910.

Bouillaut L, Perchat S, Arold S, Zorrilla S, Slamti L, Henry C, Gohar M, Declerck N, Lereclus D. 2008. Molecular basis for group-specific activation of the virulence regulator PlcR by PapR heptapeptides. Nucleic Acids Res 36: 3791-3801. 
S.T. Rutherford and B.L. Bassler

Brackman G, Defoirdt T, Miyamoto C, Bossier P, Van Calenbergh S, Nelis H, Coenye T. 2008. Cinnamaldehyde and cinnamaldehyde derivatives reduce virulence in Vibrio spp. by decreasing the DNA-binding activity of the quorum sensing response regulator LuxR. BMC Microbiol 8: 149 .

Brackman G, Celen S, Baruah K, Bossier P, Van Calenbergh S, Nelis HJ, Coenye T. 2009. AI-2 quorum-sensing inhibitors affect the starvation response and reduce virulence in several Vibrio species, most likely by interfering with LuxPQ. Microbiology 155: 4114-4122.

Brackman G, Celen S, Hillaert U, Van Calenbergh S, Cos P, Maes L, Nelis HJ, Coenye T. 2011. Structure-activity relationship of cinnamaldehyde analogs as inhibitors of AI2 based quorum sensing and their effect on virulence of Vibrio spp. PLoS ONE 6: e16084.

Branny P, Pearson JP, Pesci EC, Kohler T, Iglewski BH, Van Delden C. 2001. Inhibition of quorum sensing by a Pseudomonas aeruginosa dksA homologue. J Bacteriol 183: 1531-1539.

Brillard J, Susanna K, Michaud C, Dargaignaratz C, Gohar M, Nielsen-Leroux C, Ramarao N, Kolsto AB, Nguyen-the C, Lereclus D, et al. 2008. The YvfTU twocomponent system is involved in plcR expression in $\mathrm{Ba}$ cillus cereus. BMC Microbiol 8: 183.

Brint JM, Ohman DE. 1995. Synthesis of multiple exoproducts in Pseudomonas aeruginosa is under the control of RhlR-RhlI, another set of regulators in strain PAO1 with homology to the autoinducer-responsive LuxR-Luxl family. J Bacteriol 177: 7155-7163.

Brumfitt W, Hamilton-Miller J. 1989. Methicillin-resistant Staphylococcus aureus. N Engl J Med 320: 1188-1196.

Callegan MC, Kane ST, Cochran DC, Gilmore MS, Gominet M, Lereclus D. 2003. Relationship of plcR-regulated factors to Bacillus endophthalmitis virulence. Infect Immun 71: 3116-3124.

Carroll PA, Tashima KT, Rogers MB, DiRita VJ, Calderwood SB. 1997. Phase variation in $t c p H$ modulates expression of the ToxR regulon in Vibrio cholerae. Mol Microbiol 25: 1099-1111.

Case RJ, Labbate M, Kjelleberg S. 2008. AHL-driven quorum-sensing circuits: their frequency and function among the Proteobacteria. Isme J 2: 345-349.

Chen X, Schauder S, Potier N, Van Dorsselaer A, Pelczer I, Bassler BL, Hughson FM. 2002. Structural identification of a bacterial quorum-sensing signal containing boron. Nature 415: 545-549.

Chen G, Swem LR, Swem DL, Stauff DL, O’Loughlin CT, Jeffrey PD, Bassler BL, Hughson FM. 2011. A strategy for antagonizing quorum sensing. Mol Cell 42: 199-209.

Cheung AL, Projan SJ. 1994. Cloning and sequencing of sarA of Staphylococcus aureus, a gene required for the expression of agr. J Bacteriol 176: 4168-4172.

Chugani S, Greenberg EP. 2007. The influence of human respiratory epithelia on Pseudomonas aeruginosa gene expression. Microb Pathog 42: 29-35.

Declerck N, Bouillaut L, Chaix D, Rugani N, Slamti L, Hoh F, Lereclus D, Arold ST. 2007. Structure of PlcR: Insights into virulence regulation and evolution of quorum sensing in Gram-positive bacteria. Proc Natl Acad Sci 104: 18490-18495.
De Kievit TR. 2008. Quorum sensing in Pseudomonas aeruginosa biofilms. Environ Microbiol 11: 279-288.

de Kievit T, Seed PC, Nezezon J, Passador L, Iglewski BH. 1999. RsaL, a novel repressor of virulence gene expression in Pseudomonas aeruginosa. J Bacteriol 181: 2175-2184.

Dekimpe V, Deziel E. 2009. Revisiting the quorum-sensing hierarchy in Pseudomonas aeruginosa: The transcriptional regulator RhlR regulates LasR-specific factors. Microbiology 155: 712-723.

Deziel E, Lepine F, Milot S, Villemur R. 2003. rhlA is required for the production of a novel biosurfactant promoting swarming motility in Pseudomonas aeruginosa: 3 (3-hydroxyalkanoyloxy)alkanoic acids (HAAs), the precursors of rhamnolipids. Microbiology 149: 2005-2013.

Deziel E, Lepine F, Milot S, He J, Mindrinos MN, Tompkins RG, Rahme LG. 2004. Analysis of Pseudomonas aeruginosa 4-hydroxy-2-alkylquinolines (HAQs) reveals a role for 4-hydroxy-2-heptylquinoline in cell-to-cell communication. Proc Natl Acad Sci 101: 1339-1344.

Diggle SP, Matthijs S, Wright VJ, Fletcher MP, Chhabra SR, Lamont IL, Kong X, Hider RC, Cornelis P, Camara M, et al. 2007. The Pseudomonas aeruginosa 4-quinolone signal molecules HHQ and PQS play multifunctional roles in quorum sensing and iron entrapment. Chem Biol 14: $87-96$.

Dong YH, Zhang XF, Xu JL, Tan AT, Zhang LH. 2005. VqsM, a novel AraC-type global regulator of quorum-sensing signalling and virulence in Pseudomonas aeruginosa. Mol Microbiol 58: 552-564.

Dufour P, Jarraud S, Vandenesch F, Greenland T, Novick RP, Bes M, Etienne J, Lina G. 2002. High genetic variability of the agr locus in Staphylococcus species. J Bacteriol 184: $1180-1186$.

Dunman PM, Murphy E, Haney S, Palacios D, TuckerKellogg G, Wu S, Brown EL, Zagursky RJ, Shlaes D, Projan SJ. 2001. Transcription profiling-based identification of Staphylococcus aureus genes regulated by the agr and/or sarA loci. J Bacteriol 183: 7341-7353.

Dunny GM. 2007. The peptide pheromone-inducible conjugation system of Enterococcus faecalis plasmid pCF10: Cell-cell signalling, gene transfer, complexity and evolution. Philos Trans R Soc Lond B Biol Sci 362: 1185-1193.

Engebrecht J, Silverman M. 1984. Identification of genes and gene products necessary for bacterial bioluminescence. Proc Natl Acad Sci 81: 4154-4158.

Engebrecht J, Nealson K, Silverman M. 1983. Bacterial bioluminescence: Isolation and genetic analysis of functions from Vibrio fischeri. Cell 32: 773-781.

Faruque SM, Albert MJ, Mekalanos JJ. 1998. Epidemiology, genetics, and ecology of toxigenic Vibrio cholerae. Microbiol Mol Biol Rev 62: 1301-1314.

Federle MJ, Bassler BL. 2003. Interspecies communication in bacteria. J Clin Invest 112: 1291-1299.

Fleming V, Feil E, Sewell AK, Day N, Buckling A, Massey RC. 2006. Agr interference between clinical Staphylococcus aureus strains in an insect model of virulence. J Bacteriol 188: $7686-7688$.

Freeman JA, Bassler BL. 1999a. A genetic analysis of the function of LuxO, a two-component response regulator involved in quorum sensing in Vibrio harveyi. Mol Microbiol 31: 665-677. 
Freeman JA, Bassler BL. 1999b. Sequence and function of LuxU: A two-component phosphorelay protein that regulates quorum sensing in Vibrio harveyi. J Bacteriol 181: 899-906.

Frenzel E, Doll V, Pauthner M, Lucking G, Scherer S, EhlingSchulz M. 2012. CodY orchestrates the expression of virulence determinants in emetic Bacillus cereus by impacting key regulatory circuits. Mol Microbiol 85: 67-88.

Fuqua WC, Winans SC. 1994. A LuxR-LuxI type regulatory system activates Agrobacterium Ti plasmid conjugal transfer in the presence of a plant tumor metabolite. J Bacteriol 176: 2796-2806.

Fuqua C, Parsek MR, Greenberg EP. 2001. Regulation of gene expression by cell-to-cell communication: Acyl-homoserine lactone quorum sensing. Annu Rev Genet 35: 439-468.

Gallagher LA, McKnight SL, Kuznetsova MS, Pesci EC, Manoil C. 2002. Functions required for extracellular quinolone signaling by Pseudomonas aeruginosa. J Bacteriol 184: 6472-6480.

Gambello MJ, Iglewski BH. 1991. Cloning and characterization of the Pseudomonas aeruginosa lasR gene, a transcriptional activator of elastase expression. J Bacteriol 173: 3000-3009.

Gambello MJ, Kaye S, Iglewski BH. 1993. LasR of Pseudomonas aeruginosa is a transcriptional activator of the alkaline protease gene (apr) and an enhancer of exotoxin A expression. Infect Immun 61: 1180-1184.

Geisinger E, Adhikari RP, Jin R, Ross HF, Novick RP. 2006. Inhibition of rot translation by RNAIII, a key feature of agr function. Mol Microbiol 61: 1038-1048.

Geisinger E, Muir TW, Novick RP. 2009. agr receptor mutants reveal distinct modes of inhibition by staphylococcal autoinducing peptides. Proc Natl Acad Sci 106: 1216-1221.

Geske GD, Wezeman RJ, Siegel AP, Blackwell HE. 2005. Small molecule inhibitors of bacterial quorum sensing and biofilm formation. J Am Chem Soc 127: $12762-$ 12763.

Geske GD, O'Neill JC, Miller DM, Mattmann ME, Blackwell HE. 2007. Modulation of bacterial quorum sensing with synthetic ligands: Systematic evaluation of $\mathrm{N}$-acylated homoserine lactones in multiple species and new insights into their mechanisms of action. JAm Chem Soc 129: 13613-13625.

Geske GD, Mattmann ME, Blackwell HE. 2008. Evaluation of a focused library of $\mathrm{N}$-aryl L-homoserine lactones reveals a new set of potent quorum sensing modulators. Bioorg Med Chem Lett 18: 5978-5981.

Glansdorp FG, Thomas GL, Lee JK, Dutton JM, Salmond GP, Welch M, Spring DR. 2004. Synthesis and stability of small molecule probes for Pseudomonas aeruginosa quorum sensing modulation. Org Biomol Chem 2: $3329-3336$

Gohar M, Okstad OA, Gilois N, Sanchis V, Kolsto AB, Lereclus D. 2002. Two-dimensional electrophoresis analysis of the extracellular proteome of Bacillus cereus reveals the importance of the PlcR regulon. Proteomics 2: 784791.

Gohar M, Faegri K, Perchat S, Ravnum S, Okstad OA, Gominet M, Kolsto AB, Lereclus D. 2008. The PlcR virulence regulon of Bacillus cereus. PLoS ONE 3: e2793.
Gominet M, Slamti L, Gilois N, Rose M, Lereclus D. 2001. Oligopeptide permease is required for expression of the Bacillus thuringiensis plcR regulon and for virulence. Mol Microbiol 40: 963-975.

Gottesman S. 2004. The small RNA regulators of Escherichia coli: Roles and mechanisms. Annu Rev Microbiol 58: 303328.

Gould TA, Schweizer HP, Churchill ME. 2004. Structure of the Pseudomonas aeruginosa acyl-homoserinelactone synthase LasI. Mol Microbiol 53: 1135-1146.

Gupta R, Gobble TR, Schuster M. 2009. GidA posttranscriptionally regulates $r h l$ quorum sensing in Pseudomonas aeruginosa. J Bacteriol 191: 5785-5792.

Hammer BK, Bassler BL. 2003. Quorum sensing controls biofilm formation in Vibrio cholerae. Mol Microbiol 50: 101-104.

Hastings JW, Greenberg EP. 1999. Quorum sensing: The explanation of a curious phenomenon reveals a common characteristic of bacteria. J Bacteriol 181: 2667-2668.

Havarstein LS, Coomaraswamy G, Morrison DA. 1995. An unmodified heptadecapeptide pheromone induces competence for genetic transformation in Streptococcus pneumoniae. Proc Natl Acad Sci 92: 11140-11144.

Henke JM, Bassler BL. 2004. Three parallel quorum-sensing systems regulate gene expression in Vibrio harveyi. J Bacteriol 186: 6902-6914.

Hentzer M, Riedel K, Rasmussen TB, Heydorn A, Andersen JB, Parsek MR, Rice SA, Eberl L, Molin S, Hoiby N, et al. 2002. Inhibition of quorum sensing in Pseudomonas aeruginosa biofilm bacteria by a halogenated furanone compound. Microbiology 148: 87-102.

Heurlier K, Denervaud V, Pessi G, Reimmann C, Haas D. 2003. Negative control of quorum sensing by RpoN (sigma54) in Pseudomonas aeruginosa PAO1. J Bacteriol 185: $2227-2235$.

Higgins DE, Nazareno E, DiRita VJ. 1992. The virulence gene activator ToxT from Vibrio cholerae is a member of the AraC family of transcriptional activators. J Bacteriol 174: 6974-6980.

Higgins DA, Pomianek ME, Kraml CM, Taylor RK, Semmelhack MF, Bassler BL. 2007. The major Vibrio cholerae autoinducer and its role in virulence factor production. Nature 450: 883-886.

Hoch JA, Silhavy TJ. 1995. Two-component signal transduction. ASM Press, Washington, DC.

Hogardt M, Roeder M, Schreff AM, Eberl L, Heesemann J. 2004. Expression of Pseudomonas aeruginosa exoS is controlled by quorum sensing and RpoS. Microbiology 150: 843-851.

Hsueh YH, Somers EB, Lereclus D, Wong AC. 2006. Biofilm formation by Bacillus cereus is influenced by PlcR, a pleiotropic regulator. Appl Environ Microbiol 72: 50895092.

Inouye M, Dutta R. 2003. Histidine kinases in signal transduction. Academic, London.

Ishida T, Ikeda T, Takiguchi N, Kuroda A, Ohtake H, Kato J. 2007. Inhibition of quorum sensing in Pseudomonas aeruginosa by $\mathrm{N}$-acyl cyclopentylamides. Appl Environ $\mathrm{Mi}$ crobiol 73: 3183-3188.

Janzon L, Arvidson S. 1990. The role of the $\delta$-lysin gene (hld) in the regulation of virulence genes by the accessory 
gene regulator (agr) in Staphylococcus aureus. EMBO J 9: 1391-1399.

Jarraud S, Lyon GJ, Figueiredo AM, Gerard L, Vandenesch F, Etienne J, Muir TW, Novick RP. 2000. Exfoliatin-producing strains define a fourth agr specificity group in Staphylococcus aureus. J Bacteriol 182: 6517-6522.

Jensen V, Lons D, Zaoui C, Bredenbruch F, Meissner A, Dieterich G, Munch R, Haussler S. 2006. RhlR expression in Pseudomonas aeruginosa is modulated by the Pseudomonas quinolone signal via PhoB-dependent and -independent pathways. J Bacteriol 188: 8601-8606.

Ji G, Beavis R, Novick RP. 1997. Bacterial interference caused by autoinducing peptide variants. Science 276: $2027-$ 2030.

Ji G, Beavis RC, Novick RP. 1995. Cell density control of staphylococcal virulence mediated by an octapeptide pheromone. Proc Natl Acad Sci 92: 12055-12059.

Jobling MG, Holmes RK. 1997. Characterization of hapR, a positive regulator of the Vibrio cholerae HA/protease gene hap, and its identification as a functional homologue of the Vibrio harveyi luxR gene. Mol Microbiol 26: 1023-1034.

Juhas M, Wiehlmann L, Huber B, Jordan D, Lauber J, Salunkhe P, Limpert AS, von Gotz F, Steinmetz I, Eberl L, et al. 2004. Global regulation of quorum sensing and virulence by VqsR in Pseudomonas aeruginosa. Microbiology 150: 831-841.

Kalkum M, Lyon GJ, Chait BT. 2003. Detection of secreted peptides by using hypothesis-driven multistage mass spectrometry. Proc Natl Acad Sci 100: 2795-2800.

Kaplan HB, Greenberg EP. 1985. Diffusion of autoinducer is involved in regulation of the Vibrio fischeri luminescence system. J Bacteriol 163: 1210-1214.

Kay E, Humair B, Denervaud V, Riedel K, Spahr S, Eberl L, Valverde C, Haas D. 2006. Two GacA-dependent small RNAs modulate the quorum-sensing response in Pseudomonas aeruginosa. J Bacteriol 188: 6026-6033.

Kim C, Kim J, Park HY, Park HJ, Lee JH, Kim CK, Yoon J. 2008. Furanone derivatives as quorum-sensing antagonists of Pseudomonas aeruginosa. Appl Microbiol Biotechnol 80: 37-47.

Kiratisin P, Tucker KD, Passador L. 2002. LasR, a transcriptional activator of Pseudomonas aeruginosa virulence genes, functions as a multimer. J Bacteriol 184: 4912 4919.

Kleerebezem M, Quadri LE, Kuipers OP, de Vos WM. 1997. Quorum sensing by peptide pheromones and two-component signal-transduction systems in Gram-positive bacteria. Mol Microbiol 24: 895-904.

Kovacikova G, Skorupski K. 1999. A Vibrio cholerae LysR homolog, AphB, cooperates with AphA at the $t c p P H$ promoter to activate expression of the ToxR virulence cascade. J Bacteriol 181: 4250-4256.

Kovacikova G, Skorupski K. 2001. Overlapping binding sites for the virulence gene regulators AphA, AphB and cAMP$\mathrm{CRP}$ at the Vibrio cholerae tcpPH promoter. Mol Microbiol 41: 393-407.

Kovacikova G, Skorupski K. 2002. Regulation of virulence gene expression in Vibrio cholerae by quorum sensing: HapR functions at the aphA promoter. Mol Microbiol 46: $1135-1147$.
Krasteva PV, Fong JC, Shikuma NJ, Beyhan S, Navarro MV, Yildiz FH, Sondermann H. 2010. Vibrio cholerae VpsT regulates matrix production and motility by directly sensing cyclic di-GMP. Science 327: 866-868.

Latifi A, Foglino M, Tanaka K, Williams P, Lazdunski A. 1996. A hierarchical quorum-sensing cascade in Pseudomonas aeruginosa links the transcriptional activators LasR and RhIR (VsmR) to expression of the stationaryphase sigma factor RpoS. Mol Microbiol 21: 1137-1146.

Lauderdale KJ, Boles BR, Cheung AL, Horswill AR. 2009. Interconnections between Sigma B, agr, and proteolytic activity in Staphylococcus aureus biofilm maturation. Infect Immun 77: 1623-1635.

Lazazzera BA. 2001. The intracellular function of extracellular signaling peptides. Peptides 22: 1519-1527.

Ledgham F, Ventre I, Soscia C, Foglino M, Sturgis JN, Lazdunski A. 2003. Interactions of the quorum sensing regulator QscR: interaction with itself and the other regulators of Pseudomonas aeruginosa LasR and RhlR. Mol Microbiol 48: 199-210.

Lee JH, Lequette Y, Greenberg EP. 2006. Activity of purified QscR, a Pseudomonas aeruginosa orphan quorum-sensing transcription factor. Mol Microbiol 59: 602-609.

Lenz DH, Mok KC, Lilley BN, Kulkarni RV, Wingreen NS, Bassler BL. 2004. The small RNA chaperone Hfq and multiple small RNAs control quorum sensing in Vibrio harveyi and Vibrio cholerae. Cell 118: 69-82.

Lequette Y, Lee JH, Ledgham F, Lazdunski A, Greenberg EP. 2006. A distinct QscR regulon in the Pseudomonas aeruginosa quorum-sensing circuit. J Bacteriol 188: 33653370.

Lereclus D, Agaisse H, Gominet M, Salamitou S, Sanchis V. 1996. Identification of a Bacillus thuringiensis gene that positively regulates transcription of the phosphatidylinositol-specific phospholipase $\mathrm{C}$ gene at the onset of the stationary phase. J Bacteriol 178: 2749-2756.

Lereclus D, Agaisse H, Grandvalet C, Salamitou S, Gominet M. 2000. Regulation of toxin and virulence gene transcription in Bacillus thuringiensis. Int J Med Microbiol 290: 295-299.

Liang X, Zheng L, Landwehr C, Lunsford D, Holmes D, Ji Y. 2005. Global regulation of gene expression by ArlRS, a two-component signal transduction regulatory system of Staphylococcus aureus. J Bacteriol 187: 5486-5492.

Lilley BN, Bassler BL. 2000. Regulation of quorum sensing in Vibrio harveyi by LuxO and sigma-54. Mol Microbiol 36: $940-954$.

Lim B, Beyhan S, Meir J, Yildiz FH. 2006. Cyclic-diGMP signal transduction systems in Vibrio cholerae: Modulation of rugosity and biofilm formation. Mol Microbiol 60: 331-348.

Lim B, Beyhan S, Yildiz FH. 2007. Regulation of Vibrio polysaccharide synthesis and virulence factor production by CdgC, a GGDEF-EAL domain protein, in Vibrio cholerae. J Bacteriol 189: 717-729.

Lin W, Kovacikova G, Skorupski K. 2007. The quorum sensing regulator HapR downregulates the expression of the virulence gene transcription factor AphA in Vibrio cholerae by antagonizing Lrp- and VpsR-mediated activation. Mol Microbiol 64: 953-967. 
Lina G, Jarraud S, Ji G, Greenland T, Pedraza A, Etienne J, Novick RP, Vandenesch F. 1998. Transmembrane topology and histidine protein kinase activity of AgrC, the agr signal receptor in Staphylococcus aureus. Mol Microbiol 28: $655-662$.

Lintz MJ, Oinuma K, Wysoczynski CL, Greenberg EP, Churchill ME. 2011. Crystal structure of QscR, a Pseudomonas aeruginosa quorum sensing signal receptor. Proc Natl Acad Sci 108: 15763-15768.

Liu HB, Lee JH, Kim JS, Park S. 2010. Inhibitors of the Pseudomonasaeruginosa quorum-sensing regulator QscR. Biotechnol Bioeng 106: 119-126.

Lowy FD. 1998. Staphylococcus aureus infections. N Engl J Med 339: 520-532.

Lyczak JB, Cannon CL, Pier GB. 2002. Lung infections associated with cystic fibrosis. Clin Microbiol Rev 15: 194222.

Lyon GJ, Mayville P, Muir TW, Novick RP. 2000. Rational design of a global inhibitor of the virulence response in Staphylococcus aureus, based in part on localization of the site of inhibition to the receptor-histidine kinase AgrC. Proc Natl Acad Sci 97: 13330-13335.

Lyon GJ, Wright JS, Muir TW, Novick RP. 2002. Key determinants of receptor activation in the agr autoinducing peptides of Staphylococcus aureus. Biochemistry 41: 10095-10104.

Magnuson R, Solomon J, Grossman AD. 1994. Biochemical and genetic characterization of a competence pheromone from B. subtilis. Cell 77: 207-216.

Majerczyk CD, Sadykov MR, Luong TT, Lee C, Somerville GA, Sonenshein AL. 2008. Staphylococcus aureus CodY negatively regulates virulence gene expression. $J$ Bacteriol 190: 2257-2265.

Majerczyk CD, Dunman PM, Luong TT, Lee CY, Sadykov MR, Somerville GA, Bodi K, Sonenshein AL. 2010. Direct targets of CodY in Staphylococcus aureus. J Bacteriol 192: 2861-2877.

Manna AC, Cheung AL. 2003. sarU, a sarA homolog, is repressed by SarT and regulates virulence genes in Staphylococcus aureus. Infect Immun 71: 343-353.

Manna AC, Cheung AL. 2006a. Expression of SarX, a negative regulator of $a g r$ and exoprotein synthesis, is activated by MgrA in Staphylococcus aureus. J Bacteriol 188: 4288-4299.

Manna AC, Cheung AL. 2006b. Transcriptional regulation of the agr locus and the identification of DNA binding residues of the global regulatory protein SarR in Staphylococcus aureus. Mol Microbiol 60: 1289-1301.

Massey RC, Horsburgh MJ, Lina G, Hook M, Recker M. 2006. The evolution and maintenance of virulence in Staphylococcus aureus: A role for host-to-host transmission? Nat Rev Microbiol 4: 953-958.

Matson JS, Withey JH, DiRita VJ. 2007. Regulatory networks controlling Vibrio cholerae virulence gene expression. Infect Immun 75: 5542-5549.

Mattmann ME, Blackwell HE. 2010. Small molecules that modulate quorum sensing and control virulence in Pseudomonas aeruginosa. J Org Chem 75: 6737-6746.

Mattmann ME, Geske GD, Worzalla GA, Chandler JR, Sappington KJ, Greenberg EP, Blackwell HE. 2008. Synthetic ligands that activate and inhibit a quorum-sensing regulator in Pseudomonas aeruginosa. Bioorg Med Chem Lett 18: 3072-3075.

Mattmann ME, Shipway PM, Heth NJ, Blackwell HE. 2011. Potent and selective synthetic modulators of a quorum sensing repressor in Pseudomonas aeruginosa identified from second-generation libraries of $\mathrm{N}$-acylated L-homoserine lactones. Chembiochem 12: 942-949.

Mayville P, Ji G, Beavis R, Yang H, Goger M, Novick RP, Muir TW. 1999. Structure-activity analysis of synthetic autoinducing thiolactone peptides from Staphylococcus aureus responsible for virulence. Proc Natl Acad Sci 96: $1218-1223$.

McClean KH, Winson MK, Fish L, Taylor A, Chhabra SR, Camara M, Daykin M, Lamb JH, Swift S, Bycroft BW, et al. 1997. Quorum sensing and Chromobacterium violaceum: Exploitation of violacein production and inhibition for the detection of $\mathrm{N}$-acylhomoserine lactones. $\mathrm{Mi}$ crobiology 143 (Pt 12): 3703-3711.

McDowell P, Affas Z, Reynolds C, Holden MT, Wood SJ, Saint S, Cockayne A, Hill PJ, Dodd CE, Bycroft BW, et al. 2001. Structure, activity and evolution of the group I thiolactone peptide quorum-sensing system of Staphylococcus aureus. Mol Microbiol 41: 503-512.

McInnis CE, Blackwell HE. 2011. Thiolactone modulators of quorum sensing revealed through library design and screening. Bioorg Med Chem 19: 4820-4828.

Medina G, Juarez K, Diaz R, Soberon-Chavez G. 2003. Transcriptional regulation of Pseudomonas aeruginosa rhlR, encoding a quorum-sensing regulatory protein. Microbiology 149: 3073-3081.

Mena KD, Gerba CP. 2009. Risk assessment of Pseudomonas aeruginosa in water. Rev Environ Contam Toxicol 201: $71-115$.

Miller MB, Skorupski K, Lenz DH, Taylor RK, Bassler BL. 2002. Parallel quorum sensing systems converge to regulate virulence in Vibrio cholerae. Cell 110: 303-314.

More MI, Finger LD, Stryker JL, Fuqua C, Eberhard A, Winans SC. 1996. Enzymatic synthesis of a quorum-sensing autoinducer through use of defined substrates. Science 272: $1655-1658$.

Morfeldt E, Taylor D, von Gabain A, Arvidson S. 1995. Activation of $\alpha$-toxin translation in Staphylococcus aureus by the trans-encoded antisense RNA RNAIII. EMBO J 14: 4569-4577.

Morici LA, Carterson AJ, Wagner VE, Frisk A, Schurr JR, Honer zu Bentrup K, Hassett DJ, Iglewski BH, Sauer K, Schurr MJ. 2007. Pseudomonas aeruginosa AlgR represses the Rhl quorum-sensing system in a biofilm-specific manner. J Bacteriol 189: 7752-7764.

Muh U, Hare BJ, Duerkop BA, Schuster M, Hanzelka BL, Heim R, Olson ER, Greenberg EP. 2006a. A structurally unrelated mimic of a Pseudomonas aeruginosa acyl-homoserine lactone quorum-sensing signal. Proc Natl Acad Sci 103: 16948-16952.

Muh U, Schuster M, Heim R, Singh A, Olson ER, Greenberg EP. 2006b. Novel Pseudomonas aeruginosa quorumsensing inhibitors identified in an ultra-high-throughput screen. Antimicrob Agents Chemother 50: 3674-3679.

Mulcahy H, Lewenza S. 2011. Magnesium limitation is an environmental trigger of the Pseudomonas aeruginosa biofilm lifestyle. PLoS ONE 6: e23307. 
Nadell CD, Bassler BL. 2011. A fitness trade-off between local competition and dispersal in Vibrio cholerae biofilms. Proc Natl Acad Sci 108: 14181-14185.

Nakayama J, Cao Y, Horii T, Sakuda S, Akkermans AD, de Vos WM, Nagasawa H. 2001. Gelatinase biosynthesis-activating pheromone: A peptide lactone that mediates a quorum sensing in Enterococcus faecalis. Mol Microbiol 41: $145-154$.

Neiditch MB, Federle MJ, Miller ST, Bassler BL, Hughson FM. 2005. Regulation of LuxPQ receptor activity by the quorum-sensing signal autoinducer-2. Mol Cell 18: 507-518.

Neiditch MB, Federle MJ, Pompeani AJ, Kelly RC, Swem DL, Jeffrey PD, Bassler BL, Hughson FM. 2006. Ligand-induced asymmetry in histidine sensor kinase complex regulates quorum sensing. Cell 126: 1095-1108.

Ng WL, Bassler BL. 2009. Bacterial quorum-sensing network architectures. Annu Rev Genet 43: 197-222.

Ng WL, Wei Y, Perez LJ, Cong J, Long T, Koch M, Semmelhack MF, Wingreen NS, Bassler BL. 2010. Probing bacterial transmembrane histidine kinase receptorligand interactions with natural and synthetic molecules. Proc Natl Acad Sci 107: 5575-5580.

Ng WL, Perez LJ, Wei Y, Kraml C, Semmelhack MF, Bassler BL. 2011. Signal production and detection specificity in Vibrio CqsA/CqsS quorum-sensing systems. Mol Microbiol 79: 1407-1417.

Ng WL, Perez L, Cong J, Semmelhack MF, Bassler BL. 2012. Broad spectrum pro-quorum-sensing molecules as inhibitors of virulence in vibrios. PLoS Pathog 8: e1002767.

Niu C, Afre S, Gilbert ES. 2006. Subinhibitory concentrations of cinnamaldehyde interfere with quorum sensing. Lett Appl Microbiol 43: 489-494.

Novick RP, Geisinger E. 2008. Quorum sensing in staphylococci. Annu Rev Genet 42: 541-564.

Novick RP, Ross HF, Projan SJ, Kornblum J, Kreiswirth B, Moghazeh S. 1993. Synthesis of staphylococcal virulence factors is controlled by a regulatory RNA molecule. EMBO J 12: 3967-3975.

Novick RP, Projan SJ, Kornblum J, Ross HF, Ji G, Kreiswirth B, Vandenesch F, Moghazeh S. 1995. The agr P2 operon: An autocatalytic sensory transduction system in Staphylococcus aureus. Mol Gen Genet 248: 446-458.

O'Callaghan J, Reen FJ, Adams C, O'Gara F. 2011. Low oxygen induces the type III secretion system in Pseudomonas aeruginosa via modulation of the small RNAs rsmZ and rsmY. Microbiology 157 (Pt 12): 3417-3428.

Ochsner UA, Koch AK, Fiechter A, Reiser J. 1994. Isolation and characterization of a regulatory gene affecting rhamnolipid biosurfactant synthesis in Pseudomonas aeruginosa. J Bacteriol 176: 2044-2054.

Oglesby AG, Farrow JM 3rd, Lee JH, Tomaras AP, Greenberg EP, Pesci EC, Vasil ML. 2008. The influence of iron on Pseudomonas aeruginosa physiology: A regulatory link between iron and quorum sensing. J Biol Chem 283: $15558-15567$.

Oglesby-Sherrouse AG, Vasil ML. 2010. Characterization of a heme-regulated non-coding RNA encoded by the prrF locus of Pseudomonas aeruginosa. PLoS ONE 5: e9930.
Ohtani K, Yuan Y, Hassan S, Wang R, Wang Y, Shimizu T. 2009. Virulence gene regulation by the $a g r$ system in Clostridium perfringens. J Bacteriol 191: 3919-3927.

Oinuma K, Greenberg EP. 2011. Acyl-homoserine lactone binding to and stability of the orphan Pseudomonas aeruginosa quorum-sensing signal receptor QscR. J Bacteriol 193: $421-428$

Okada M, Sato I, Cho SJ, Iwata H, Nishio T, Dubnau D, Sakagami Y. 2005. Structure of the Bacillus subtilis quorum-sensing peptide pheromone ComX. Nat Chem Biol 1: $23-24$.

Okstad OA, Gominet M, Purnelle B, Rose M, Lereclus D, Kolsto AB. 1999. Sequence analysis of three Bacillus cereus loci carrying PIcR-regulated genes encoding degradative enzymes and enterotoxin. Microbiology 145 ( $\mathrm{Pt} \mathrm{11):}$ 3129-3138.

Otto M. 2004. Quorum-sensing control in Staphylococcia target for antimicrobial drug therapy? FEMS Microbiol Lett 241: 135-141.

Otto M, Sussmuth R, Jung G, Gotz F. 1998. Structure of the pheromone peptide of the Staphylococcus epidermidis agr system. FEBS Lett 424: 89-94.

Papenfort K, Vogel J. 2010. Regulatory RNA in bacterial pathogens. Cell Host Microbe 8: 116-127.

Park J, Jagasia R, Kaufmann GF, Mathison JC, Ruiz DI, Moss JA, Meijler MM, Ulevitch RJ, Janda KD. 2007. Infection control by antibody disruption of bacterial quorum sensing signaling. Chem Biol 14: 1119-1127.

Park J, Kaufmann GF, Bowen JP, Arbiser JL, Janda KD. 2008. Solenopsin A, a venom alkaloid from the fire ant Solenopsis invicta, inhibits quorum-sensing signaling in $\mathrm{Pseu}$ domonas aeruginosa. J Infect Dis 198: 1198-1201.

Parsek MR, Val DL, Hanzelka BL, Cronan JE Jr, Greenberg EP. 1999. Acyl homoserine-lactone quorum-sensing signal generation. Proc Natl Acad Sci 96: 4360-4365.

Passador L, Cook JM, Gambello MJ, Rust L, Iglewski BH. 1993. Expression of Pseudomonas aeruginosa virulence genes requires cell-to-cell communication. Science 260: 1127-1130.

Patriquin GM, Banin E, Gilmour C, Tuchman R, Greenberg EP, Poole K. 2008. Influence of quorum sensing and iron on twitching motility and biofilm formation in Pseudomonas aeruginosa. J Bacteriol 190: 662-671.

Pearson JP, Passador L, Iglewski BH, Greenberg EP. 1995. A second $\mathrm{N}$-acylhomoserine lactone signal produced by Pseudomonas aeruginosa. Proc Natl Acad Sci 92: 14901494.

Pesci EC, Pearson JP, Seed PC, Iglewski BH. 1997. Regulation of las and rhl quorum sensing in Pseudomonas aeruginosa. J Bacteriol 179: 3127-3132.

Pessi G, Williams F, Hindle Z, Heurlier K, Holden MT, Camara M, Haas D, Williams P. 2001. The global posttranscriptional regulator RsmA modulates production of virulence determinants and $\mathrm{N}$-acylhomoserine lactones in Pseudomonas aeruginosa. J Bacteriol 183: 6676-6683.

Peterson KM, Mekalanos JJ. 1988. Characterization of the Vibrio cholerae ToxR regulon: Identification of novel genes involved in intestinal colonization. Infect Immun 56: $2822-2829$.

Peterson S, Cline RT, Tettelin H, Sharov V, Morrison DA. 2000. Gene expression analysis of the Streptococcus 
pneumoniae competence regulons by use of DNA microarrays. J Bacteriol 182: 6192-6202.

Podbielski A, Kreikemeyer B. 2004. Cell density-dependent regulation: Basic principles and effects on the virulence of Gram-positive cocci. Int J Infect Dis 8: 81-95.

Pohl K, Francois P, Stenz L, Schlink F, Geiger T, Herbert S Goerke C, Schrenzel J, Wolz C. 2009. CodY in Staphylococcus aureus: a regulatory link between metabolism and virulence gene expression. J Bacteriol 191: 2953-2963.

Pomerantsev AP, Pomerantseva OM, Camp AS, Mukkamala R, Goldman S, Leppla SH. 2009. PapR peptide maturation: Role of the NprB protease in Bacillus cereus $569 \mathrm{PlcR} / \mathrm{PapR}$ global gene regulation. FEMS Immunol Med Microbiol 55: 361-377.

Pompeani AJ, Irgon JJ, Berger MF, Bulyk ML, Wingreen NS, Bassler BL. 2008. The Vibrio harveyi master quorum sensing regulator, LuxR, a TetR-type protein is both an activator and a repressor: DNA recognition and binding specificity at target promoters. Mol Microbiol 70: 76-88.

Pottathil M, Lazazzera BA. 2003. The extracellular Phr peptide-Rap phosphatase signaling circuit of Bacillus subtilis. Front Biosci 8: d32-d45.

Queck SY, Jameson-Lee M, Villaruz AE, Bach TH, Khan BA, Sturdevant DE, Ricklefs SM, Li M, Otto M. 2008. RNAIII-independent target gene control by the agr quorum-sensing system: Insight into the evolution of virulence regulation in Staphylococcus aureus. Mol Cell 32: $150-158$.

Rahman P, Dusane D, Zinjarde S, Venugopalan V, McLean R, Weber M. 2010. Quorum sensing: Implications on rhamnolipid biosurfactant production. Biotechnol Genet Eng Rev 27: 159-184.

Rasmussen TB, Skindersoe ME, Bjarnsholt T, Phipps RK, Christensen KB, Jensen PO, Andersen JB, Koch B, Larsen TO, Hentzer M, et al. 2005. Identity and effects of quorum-sensing inhibitors produced by Penicillium species. Microbiology 151: 1325-1340.

Ren D, Zuo R, Wood TK. 2005. Quorum-sensing antagonist (5Z)-4-bromo-5-(bromomethylene)-3-butyl-2(5H)furanone influences siderophore biosynthesis in Pseudomonas putida and Pseudomonas aeruginosa. Appl Microbiol Biotechnol 66: 689-695.

Riedel CU, Monk IR, Casey PG, Waidmann MS, Gahan CG, Hill C. 2009. AgrD-dependent quorum sensing affects biofilm formation, invasion, virulence and global gene expression profiles in Listeria monocytogenes. Mol Microbiol 71: 1177-1189.

Rocha-Estrada J, Aceves-Diez AE, Guarneros G, de la Torre M. 2010. The RNPP family of quorum-sensing proteins in Gram-positive bacteria. Appl Microbiol Biotechnol 87: 913-923.

Ruby EG. 1996. Lessons from a cooperative, bacterial-animal association: The Vibrio fischeri-Euprymna scolopes light organ symbiosis. Annu Rev Microbiol 50: 591-624.

Rutherford ST, van Kessel JC, Shao Y, Bassler BL. 2011. AphA and LuxR/HapR reciprocally control quorum sensing in vibrios. Genes Dev 25: 397-408.

Saenz HL, Augsburger V, Vuong C, Jack RW, Gotz F, Otto M. 2000. Inducible expression and cellular location of AgrB, a protein involved in the maturation of the staphylococcal quorum-sensing pheromone. Arch Microbiol 174: 452 455.
Said-Salim B, Dunman PM, McAleese FM, Macapagal D, Murphy E, McNamara PJ, Arvidson S, Foster TJ, Projan SJ, Kreiswirth BN. 2003. Global regulation of Staphylococcus aureus genes by Rot. J Bacteriol 185: 610-619.

Schaefer AL, Val DL, Hanzelka BL, Cronan JE Jr, Greenberg EP. 1996. Generation of cell-to-cell signals in quorum sensing: Acyl homoserine lactone synthase activity of a purified Vibrio fischeri LuxI protein. Proc Natl Acad Sci 93: 9505-9509.

Schauder S, Shokat K, Surette MG, Bassler BL. 2001. The LuxS family of bacterial autoinducers: Biosynthesis of a novel quorum-sensing signal molecule. Mol Microbiol 41: 463-476.

Schmidt KA, Manna AC, Gill S, Cheung AL. 2001. SarT, a repressor of $\alpha$-hemolysin in Staphylococcus aureus. Infect Immun 69: 4749-4758.

Schramm VL, Gutierrez JA, Cordovano G, Basu I, Guha C, Belbin TJ, Evans GB, Tyler PC, Furneaux RH. 2008. Transition state analogues in quorum sensing and SAM recycling. Nucleic Acids Symp Ser (Oxf) 75-76.

Schuster M, Greenberg EP. 2006. A network of networks: Quorum-sensing gene regulation in Pseudomonas aeruginosa. Int J Med Microbiol 296: 73-81.

Schuster M, Greenberg EP. 2007. Early activation of quorum sensing in Pseudomonas aeruginosa reveals the architecture of a complex regulon. BMC Genomics 8: 287.

Schuster M, Lostroh CP, Ogi T, Greenberg EP. 2003. Identification, timing, and signal specificity of Pseudomonas aeruginosa quorum-controlled genes: A transcriptome analysis. J Bacteriol 185: 2066-2079.

Schuster M, Urbanowski ML, Greenberg EP. 2004. Promoter specificity in Pseudomonas aeruginosa quorum sensing revealed by DNA binding of purified LasR. Proc Natl Acad Sci 101: 15833-15839.

Seed PC, Passador L, Iglewski BH. 1995. Activation of the Pseudomonas aeruginosa lasI gene by LasR and the Pseudomonas autoinducer PAI: An autoinduction regulatory hierarchy. J Bacteriol 177: 654-659.

Seidl K, Stucki M, Ruegg M, Goerke C, Wolz C, Harris L, Berger-Bachi B, Bischoff M. 2006. Staphylococcus aureus CcpA affects virulence determinant production and antibiotic resistance. Antimicrob Agents Chemother 50: 1183-1194.

Shao Y, Bassler BL. 2012. Quorum-sensing non-coding small RNAs use unique pairing regions to differentially control mRNA targets. Mol Microbiol 83: 599-611.

Shenkman B, Rubinstein E, Cheung AL, Brill GE, Dardik R, Tamarin I, Savion N, Varon D. 2001. Adherence properties of Staphylococcus aureus under static and flow conditions: Roles of agr and sar loci, platelets, and plasma ligands. Infect Immun 69: 4473-4478.

Shikuma NJ, Fong JC, Odell LS, Perchuk BS, Laub MT, Yildiz FH. 2009. Overexpression of VpsS, a hybrid sensor kinase, enhances biofilm formation in Vibrio cholerae. J Bacteriol 191: 5147-5158.

Simon MI, Crane BR, Crane A. 2007. Two-component signaling systems. Academic, San Diego.

Skorupski K, Taylor RK. 1997. Control of the ToxR virulence regulon in Vibrio cholerae by environmental stimuli. Mol Microbiol 25: 1003-1009. 
Skorupski K, Taylor RK. 1999. A new level in the Vibrio cholerae ToxR virulence cascade: AphA is required for transcriptional activation of the $t c p P H$ operon. $\mathrm{Mol} \mathrm{Mi-}$ crobiol 31: 763-771.

Slamti L, Lereclus D. 2002. A cell-cell signaling peptide activates the PlcR virulence regulon in bacteria of the Bacillus cereus group. EMBO J 21: 4550-4559.

Slamti L, Lereclus D. 2005. Specificity and polymorphism of the PlcR-PapR quorum-sensing system in the Bacillus cereus group. J Bacteriol 187: 1182-1187.

Smith KM, Bu Y, Suga H. 2003. Induction and inhibition of Pseudomonas aeruginosa quorum sensing by synthetic autoinducer analogs. Chem Biol 10: 81-89.

Smith EE, Buckley DG, Wu Z, Saenphimmachak C, Hoffman LR, D’Argenio DA, Miller SI, Ramsey BW, Speert DP, Moskowitz SM, et al. 2006. Genetic adaptation by Pseudomonas aeruginosa to the airways of cystic fibrosis patients. Proc Natl Acad Sci 103: 8487-8492.

Solomon JM, Lazazzera BA, Grossman AD. 1996. Purification and characterization of an extracellular peptide factor that affects two different developmental pathways in Bacillus subtilis. Genes Dev 10: 2014-2024.

Sonnleitner E, Haas D. 2011. Small RNAs as regulators of primary and secondary metabolism in Pseudomonas species. Appl Microbiol Biotechnol 91: 63-79.

Sonnleitner E, Gonzalez N, Sorger-Domenigg T, Heeb S, Richter AS, Backofen R, Williams P, Huttenhofer A, Haas D, Blasi U. 2010. The small RNA PhrS stimulates synthesis of the Pseudomonas aeruginosa quinolone signal. Mol Microbiol 80: 868-885.

Srivastava D, Harris RC, Waters CM. 2011. Integration of cyclic di-GMP and quorum sensing in the control of $v p s T$ and aphA in Vibrio cholerae. J Bacteriol 193: 6331-6341.

Stevens AM, Dolan KM, Greenberg EP. 1994. Synergistic binding of the Vibrio fischeri LuxR transcriptional activator domain and RNA polymerase to the lux promoter region. Proc Natl Acad Sci 91: 12619-12623.

Storz G, Vogel J, Wassarman KM. 2011. Regulation by small RNAs in bacteria: Expanding frontiers. Mol Cell 43: $880-891$.

Surette MG, Miller MB, Bassler BL. 1999. Quorum sensing in Escherichia coli, Salmonella typhimurium, and Vibrio harveyi: A new family of genes responsible for autoinducer production. Proc Natl Acad Sci 96: 1639-1644.

Tamber S, Cheung AL. 2009. SarZ promotes the expression of virulence factors and represses biofilm formation by modulating SarA and agr in Staphylococcus aureus. Infect Immun 77: 419-428.

Tamber S, Reyes D, Donegan NP, Schwartzman JD, Cheung AL, Memmi G. 2010. The staphylococcus-specific gene rsr represses agr and virulence in Staphylococcus aureus. Infect Immun 78: 4384-4391.

Thoendel M, Horswill AR. 2009. Identification of Staphylococcus aureus AgrD residues required for autoinducing peptide biosynthesis. J Biol Chem 284: 21828-21838.

Thoendel M, Horswill AR. 2010. Biosynthesis of peptide signals in gram-positive bacteria. Adv Appl Microbiol 71: $91-112$.

Thoendel M, Kavanaugh JS, Flack CE, Horswill AR. 2011. Peptide signaling in the staphylococci. Chem Rev 111: 117-151.
Thomson NR, Crow MA, McGowan SJ, Cox A, Salmond GP. 2000. Biosynthesis of carbapenem antibiotic and prodigiosin pigment in Serratia is under quorum sensing control. Mol Microbiol 36: 539-556.

Tu KC, Bassler BL. 2007. Multiple small RNAs act additively to integrate sensory information and control quorum sensing in Vibrio harveyi. Genes Dev 21: 221-233.

Urbanowski ML, Lostroh CP, Greenberg EP. 2004. Reversible acyl-homoserine lactone binding to purified Vibrio $f$ scheri LuxR protein. J Bacteriol 186: 631-637.

Val DL, Cronan JE Jr. 1998. In vivo evidence that $S$-adenosylmethionine and fatty acid synthesis intermediates are the substrates for the LuxI family of autoinducer synthases. J Bacteriol 180: 2644-2651.

van Delden C, Comte R, Bally AM. 2001. Stringent response activates quorum sensing and modulates cell density-dependent gene expression in Pseudomonas aeruginosa. J Bacteriol 183: 5376-5384.

Vannini A, Volpari C, Gargioli C, Muraglia E, Cortese R, De Francesco R, Neddermann P, Marco SD. 2002. The crystal structure of the quorum sensing protein TraR bound to its autoinducer and target DNA. EMBO J 21: 4393-4401.

Vuong C, Saenz HL, Gotz F, Otto M. 2000. Impact of the agr quorum-sensing system on adherence to polystyrene in Staphylococcus aureus. J Infect Dis 182: 1688-1693.

Wagner VE, Gillis RJ, Iglewski BH. 2004. Transcriptome analysis of quorum-sensing regulation and virulence factor expression in Pseudomonas aeruginosa. Vaccine 22 (Suppl 1): S15-S20.

Waters CM, Lu W, Rabinowitz JD, Bassler BL. 2008. Quorum sensing controls biofilm formation in Vibrio cholerae through modulation of cyclic di-GMP levels and repression of vpsT. J Bacteriol 190: 2527-2536.

Watson WT, Minogue TD, Val DL, von Bodman SB, Churchill ME. 2002. Structural basis and specificity of acyl-homoserine lactone signal production in bacterial quorum sensing. Mol Cell 9: 685-694.

Weeks JN, Galindo CL, Drake KL, Adams GL, Garner HR, Ficht TA. 2010. Brucella melitensis VjbR and C12-HSL regulons: Contributions of the $\mathrm{N}$-dodecanoyl homoserine lactone signaling molecule and LuxR homologue VjbR to gene expression. BMC Microbiol 10: 167.

Wei Y, Perez LJ, Ng WL, Semmelhack MF, Bassler BL. 2011. Mechanism of Vibrio cholerae autoinducer-1 biosynthesis. ACS Chem Biol 6: 356-365.

Wei Y, Ng WL, Cong J, Bassler BL. 2012. Ligand and antagonist driven regulation of the Vibrio cholerae quorumsensing receptor CqsS. Mol Microbiol 83: 1095-1108.

Whiteley M, Lee KM, Greenberg EP. 1999. Identification of genes controlled by quorum sensing in Pseudomonas aeruginosa. Proc Natl Acad Sci 96: 13904-13909.

Wilderman PJ, Sowa NA, FitzGerald DJ, FitzGerald PC, Gottesman S, Ochsner UA, Vasil ML. 2004. Identification of tandem duplicate regulatory small RNAs in Pseudomonas aeruginosa involved in iron homeostasis. Proc Natl Acad Sci 101: 9792-9797.

Williams P, Camara M. 2009. Quorum sensing and environmental adaptation in Pseudomonas aeruginosa: A tale of regulatory networks and multifunctional signal molecules. Curr Opin Microbiol 12: 182-191. 
Withey JH, DiRita VJ. 2006. The toxbox: Specific DNA sequence requirements for activation of Vibrio cholerae virulence genes by ToxT. Mol Microbiol 59: 1779-1789.

Wu H, Song Z, Hentzer M, Andersen JB, Molin S, Givskov M, Hoiby N. 2004. Synthetic furanones inhibit quorum-sensing and enhance bacterial clearance in $\mathrm{Pseu}$ domonas aeruginosa lung infection in mice. J Antimicrob Chemother 53: 1054-1061.

Xavier KB, Bassler BL. 2005. Interference with AI-2-mediated bacterial cell-cell communication. Nature 437: $750-753$.

Xiao G, Deziel E, He J, Lepine F, Lesic B, Castonguay MH, Milot S, Tampakaki AP, Stachel SE, Rahme LG. 2006a. MvfR, a key Pseudomonas aeruginosa pathogenicity LTTR-class regulatory protein, has dual ligands. Mol Microbiol 62: 1689-1699.

Xiao G, He J, Rahme LG. 2006b. Mutation analysis of the Pseudomonas aeruginosa $m v f R$ and $p q s A B C D E$ gene promoters demonstrates complex quorum-sensing circuitry. Microbiology 152: 1679-1686.

Yao Y, Martinez-Yamout MA, Dickerson TJ, Brogan AP, Wright PE, Dyson HJ. 2006. Structure of the Escherichia coli quorum sensing protein SdiA: Activation of the folding switch by acyl homoserine lactones. J Mol Biol 355: $262-273$.

Yarwood JM, McCormick JK, Schlievert PM. 2001. Identification of a novel two-component regulatory system that acts in global regulation of virulence factors of Staphylococcus aureus. J Bacteriol 183: 1113-1123.
Yarwood JM, Bartels DJ, Volper EM, Greenberg EP. 2004. Quorum sensing in Staphylococcus aureus biofilms. J Bacteriol 186: $1838-1850$.

Yildiz FH, Liu XS, Heydorn A, Schoolnik GK. 2004. Molecular analysis of rugosity in a Vibrio cholerae O1 El Tor phase variant. Mol Microbiol 53: 497-515.

Zemanick ET, Sagel SD, Harris JK. 2011. The airway microbiome in cystic fibrosis and implications for treatment Curr Opin Pediatr 23: 319-324.

Zhang RG, Pappas KM, Brace JL, Miller PC, Oulmassov T, Molyneaux JM, Anderson JC, Bashkin JK, Winans SC, Joachimiak A. 2002. Structure of a bacterial quorumsensing transcription factor complexed with pheromone and DNA. Nature 417: 971-974.

Zhu J, Mekalanos JJ. 2003. Quorum sensing-dependent biofilms enhance colonization in Vibrio cholerae. Dev Cell 5 647-656.

Zhu J, Winans SC. 1999. Autoinducer binding by the quorum-sensing regulator TraR increases affinity for target promoters in vitro and decreases TraR turnover rates in whole cells. Proc Natl Acad Sci 96: 4832-4837.

Zhu J, Winans SC. 2001. The quorum-sensing transcriptional regulator TraR requires its cognate signaling ligand for protein folding, protease resistance, and dimerization. Proc Natl Acad Sci 98: 1507-1512.

Zhu J, Miller MB, Vance RE, Dziejman M, Bassler BL, Mekalanos JJ. 2002. Quorum-sensing regulators control virulence gene expression in Vibrio cholerae. Proc Nat Acad Sci 99: 3129-3134. 


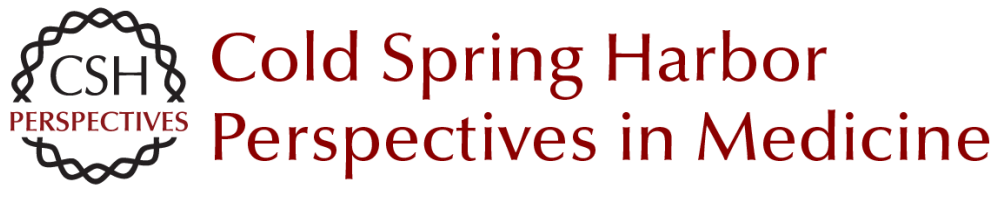

\section{Bacterial Quorum Sensing: Its Role in Virulence and Possibilities for Its Control}

Steven T. Rutherford and Bonnie L. Bassler

Cold Spring Harb Perspect Med 2012; doi: 10.1101/cshperspect.a012427

Subject Collection Bacterial Pathogenesis

Therapeutic and Prophylactic Applications of

Bacteriophage Components in Modern Medicine Sankar Adhya, Carl R. Merril and Biswajit Biswas

Vaccines, Reverse Vaccinology, and Bacterial

Pathogenesis

Isabel Delany, Rino Rappuoli and Kate L. Seib

Helicobacter and Salmonella Persistent Infection

Strategies

Denise M. Monack

Echoes of a Distant Past: The cag Pathogenicity

Island of Helicobacter pylori

Nicola Pacchiani, Stefano Censini, Ludovico Buti, et al.

RNA-Mediated Regulation in Pathogenic Bacteria Isabelle Caldelari, Yanjie Chao, Pascale Romby, et al.

The Pneumococcus: Epidemiology, Microbiology, and Pathogenesis

Birgitta Henriques-Normark and Elaine I.

Tuomanen

Pathogenesis of Meningococcemia

Mathieu Coureuil, Olivier Join-Lambert, Hervé

Lécuyer, et al.

Chlamydial Intracellular Survival Strategies

Robert J. Bastidas, Cherilyn A. Elwell, Joanne N.

Engel, et al.
Mechanisms and Biological Roles of

Contact-Dependent Growth Inhibition Systems

Christopher S. Hayes, Sanna Koskiniemi, Zachary

C. Ruhe, et al.

A Genome-Wide Perspective of Human Diversity and Its Implications in Infectious Disease Jérémy Manry and Lluis Quintana-Murci

Host Specificity of Bacterial Pathogens Andreas Bäumler and Ferric C. Fang

The Inside Story of Shigella Invasion of Intestinal Epithelial Cells

Nathalie Carayol and Guy Tran Van Nhieu

Bartonella and Brucella--Weapons and Strategies for Stealth Attack

Houchaima Ben-Tekaya, Jean-Pierre Gorvel and Christoph Dehio

Concepts and Mechanisms: Crossing Host

Barriers

Kelly S. Doran, Anirban Banerjee, Olivier Disson, et al.

Genome Dynamics in Legionella: The Basis of

Versatility and Adaptation to Intracellular

Replication

Laura Gomez-Valero and Carmen Buchrieser

Mechanisms of Francisella tularensis Intracellular

Pathogenesis

Jean Celli and Thomas C. Zahrt

For additional articles in this collection, see http://perspectivesinmedicine.cshlp.org/cgi/collection/ 